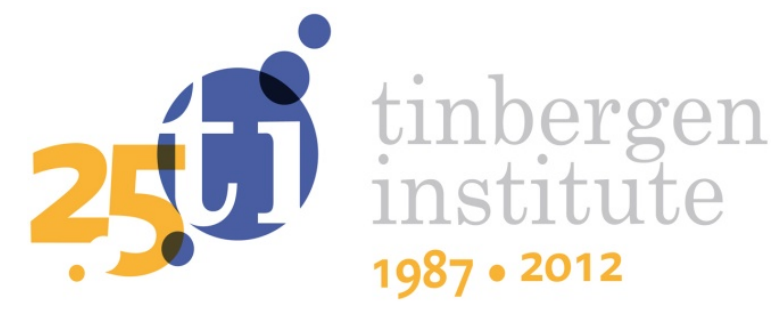

\title{
Economic Impacts of Cultural Diversity in the Netherlands: Productivity, Utility, and Sorting
}

Jessie Bakens*

Peter Mulder

Peter Nijkamp*

* Tinbergen Institute. 
Tinbergen Institute is the graduate school and research institute in economics of Erasmus University Rotterdam, the University of Amsterdam and VU University Amsterdam.

More TI discussion papers can be downloaded at http://www.tinbergen.nl

Tinbergen Institute has two locations:

Tinbergen Institute Amsterdam

Gustav Mahlerplein 117

1082 MS Amsterdam

The Netherlands

Tel.: +31(0)205251600

Tinbergen Institute Rotterdam

Burg. Oudlaan 50

3062 PA Rotterdam

The Netherlands

Tel.: +31(0)10 4088900

Fax: $+31(0) 104089031$

Duisenberg school of finance is a collaboration of the Dutch financial sector and universities, with the ambition to support innovative research and offer top quality academic education in core areas of finance.

DSF research papers can be downloaded at: http://www.dsf.nl/

Duisenberg school of finance

Gustav Mahlerplein 117

1082 MS Amsterdam

The Netherlands

Tel.: +31(0)20 5258579 


\title{
Economic Impacts of Cultural Diversity in the Netherlands: Productivity, Utility and Sorting
}

\author{
Jessie Bakens ${ }^{a, b, 1}$, Peter Mulder ${ }^{a}$, Peter Nijkamp ${ }^{a, b}$ \\ ${ }^{a}$ Department of Spatial Economics, VU University Amsterdam, the Netherlands \\ ${ }^{\mathrm{b}}$ Tinbergen Institute, Amsterdam-Rotterdam, the Netherlands
}

\section{March 2012}

\begin{abstract}
This paper identifies the role of cultural diversity in explaining spatial disparities in wages and housing prices across Dutch cities, using unique individual panel data of home owners. We distinguish between the effects of interactions-based productivity, consumption amenities and sorting of heterogeneous home owners while controlling for interactions between the labor and housing market. We find that an increase in the cultural diversity of the population positively impacts equilibrium wages and housing prices, particularly in the largest and most densely populated cities. This result is largely driven by spatial sorting of individuals in both the labor and housing market. After controlling for home owner heterogeneity we find that increasing cultural diversity no longer impacts local labor markets and negatively impacts local housing markets. The latter result is likely to be driven by a negative causal effect of increased cultural diversity on neighborhood quality that outweighs a positive effect of increased cultural diversity in consumption goods.
\end{abstract}

Key words: cultural diversity, immigrants, local amenities, sorting, housing prices, productivity JEL classification: J31, R21, R23, R31

Financial support from NORFACE research programme on Migration in Europe - Social, Economic, Cultural and Policy Dynamics is acknowledged. The authors like to thank the participants of the Workshop on Immigration held at the Federal Reserve Bank Chicago in 2011, Henri de Groot, and Thomas de Graaff for useful comments and suggestions.

\footnotetext{
${ }^{1}$ Corresponding author. Department of Spatial Economics, VU University Amsterdam, De Boelelaan 1105, 1081 HV Amsterdam, The Netherlands; Email: j.bakens@vu.nl; Tel: +31205988106
} 


\section{Introduction}

In many countries, cities not only attract native citizens but also foreign migrants. What are the economic consequences of the implied cultural diversity of cities? To answer this question, the literature to date essentially identifies three channels through which the arrival of foreign migrants influences local economies. First, immigrants may influence productivity because their different sets of skills and abilities impact local interactions between workers and firms. Second, immigrants may influence consumer utility by changing local amenities such as neighborhood quality and the diversity of available consumption goods and services. Third, the arrival of foreign migrants impacts sorting of native residents across residential and employment areas, so that the abilities and preferences of the local population and labor force change.

Often, particularly in empirical studies, these channels are explored in (relative) isolation, usually by analysing the impact of immigrants on either the housing market or the labor market. ${ }^{2}$ In contrast, this paper considers both the labor market and the housing market to evaluate the relative importance of the aforementioned three channels in explaining the role of cultural diversity in local economies. More precisely we aim to empirically identify the role of foreign migrants in explaining spatial disparities in wages and housing prices across cities by distinguishing between interactionsbased productivity effects, consumption amenities and sorting. Our sample consists of cities in the Netherlands, and makes use of new and unique individual data about home owners we are followed simultaneously in the housing and labor market between 1999 and 2008.

Economists have related cultural diversity to housing and labor markets in various ways, suggesting several different, and sometimes contrasting, means by which foreign migrants impact local economies (for more extensive descriptions see Alesina and La Ferrara 2005; Borjas 1994, 1995). As regards the labor market, wages are obviously subject to migrant-induced variations in supply shifts across education-experience groups (Borjas 2001, 2003; Card 1990, 2001; Card and Niardo 2000). In addition, immigrants may impact wages through their impact on local productivity:

\footnotetext{
${ }^{2}$ The work by Ottaviano and Peri (2006) stands out as an important exception.
} 
cross-cultural interaction on the labor market may be associated with either lower productivity because of increasing intercultural frictions ('Babel effect') or higher productivity because of increasing creativity and innovation a la Jacobs (1969) (cf. Duranton and Puga 2001, Lazear 1999, Alesina and La Ferrara 2005, Bellini et al. 2008). In addition, there is evidence that (foreign) economic migrants show a tendency toward favourable self selection for labor market success on the basis of a higher level of ability, i.e. sorting (Borjas 1987, Chiswick 1999).

More recently, increasing attention is paid in the literature to the consequences of immigration for the housing market. On the one hand, a migrant-induced increase in demand for housing of course is expected to have an upward effect on housing prices, particularly in gateway cities (Saiz 2003, 2007). On the other hand, growing migrant density may negatively impact housing prices if newly arrived immigrants' demand for housing is associated with decreasing wages, native out-migration, or even segregation (Benabou 1993, Cutler et al. 1999, Saiz and Wachter 2006).

However, although foreign migrants often locate in cities because of labor market considerations (Scott 2010), they also contribute to the diversity of man-made consumption amenities in cities (cf. Glaeser et al. 2001, Quigley 1998). As Ottaviano and Peri (2006:10) write in their seminal paper on the economic value of cultural diversity in U.S. cities: "Who can deny that Italian restaurants, French beauty shops, German breweries, Belgian chocolate stores, Russian ballets, Chinese markets, and Indian tea houses all constitute valuable consumption amenities that would be inaccessible to Americans were it not for their foreign-born residents?" Arguably, to many people this raises the attractiveness of living in cities, and this 'love of variety'-effect is thought to positively impact housing prices (Ottaviano and Peri 2005,2006 ) - thereby opposing an eventual 'native flight'.

All this suggests a role to be played for sorting: depending on their appreciation of the implied diversity of cultural values, native residents differ in their preferences for living in a multicultural environment (Baranzini et al. 2008; Bajari and Kahn 2005, 2008; Olfert and Partridge 2011). In addition, new immigrants also sort themselves across space, since they often tend to settle in 
gateway cities where other immigrants from the same country already reside (Bartel 1989, Card 2001).

As the labor market and the housing market are interrelated in various ways, ignoring this interdependent relationship may lead to biased estimates of the economic impact of cultural diversity in cities (Hoehn et al. 1987). First of all, in the context of this study, the labor market and the housing market are related as immigrants (and their families) typically are workers as well as residents, thus participating in both markets. Moreover, spatial equilibrium requires that spatial disparities in housing prices are compensated by wage differentials across space (Rosen 1974; Roback 1982). This means that, because of the impact of immigrants on housing prices, spatial disparities in migrant density are expected to induce wage and productivity differentials across cities. Conversely, spatial disparities of wages across local labor markets caused by immigrants (be it through productivity effects or supply shifts) contributes to housing price differentials across cities. Finally, as mentioned before, although immigrants often locate in cities because of labor market considerations they also influence the attractiveness of cities, which of course impacts local housing markets. This in turn, may again impact wage differentials because of spatial equilibrium dynamics.

It is because of these interactions that in the first part of the paper we consider the labor market and the housing market parallel and in the second part simultaneously, in search for the impact of cultural diversity on the economies of cities. Our strategy in this paper is as follows. First, following the seminal work by Ottaviano and Peri (2006), we estimate a Roback-like equilibrium model (Roback 1982) in which cultural diversity affects average wages and housing prices across cities through its localized effect on both the productivity of firms and the utility of consumers. Then we contrast these average effects to effects that are controlled for by sorting based on individual unobserved heterogeneity. We take advantage of the individual dimension of our panel data to evaluate to what extent the observed impact of cultural diversity on equilibrium housing prices and wages is influenced by spatial sorting of home owners in both the labor and housing market. To do so, in principle we could include fixed effects and dummies in our equilibrium model, but for reasons 
of computational tractability this cannot be properly done given the very large number of individual observations in our dataset. Therefore, we adopt the approach developed by Combes et al. (2008) to account for spatial wage disparities, and slightly modify it in order to account for both wage and housing price disparities across space. We control for sorting by explaining spatial disparities in wages and housing prices from, respectively, observed and unobserved characteristics of individual home owners, sector and home characteristics, and a local area effect that represents the unobserved local characteristics of, respectively, the local labor and housing market. Subsequently, we identify the role of cultural diversity in explaining these local area effects, controlling for interactions-based productivity effects, local amenities, and (unobserved) interactions between the labor and housing market. This is, to our best knowledge, a new identification strategy in the literature on migration and urban issues.

Using the Roback-like equilibrium framework, we find that between 1999 and 2008 an increase in cultural diversity positively impacts average housing prices as well as average wages across Dutch cities, especially in the larger cities (controlling for, respectively, average per capita income and the share of high educated). These results very much resemble the key findings presented by Ottaviano and Peri (2006) for U.S. cities between 1970 and $1990 .^{3}$ Once we explore the individual dimension of our panel data, we find strong evidence that the found results are largely driven by spatial sorting of home owners, based on the unobserved abilities and preferences in their role as both home owner and worker. After having controlled for the role of sorting, an increase in cultural diversity no longer impacts local labor markets and negatively impacts local housing markets. The latter result is likely to be driven by a negative causal effect of cultural diversity on neighborhood quality that outweighs a positive effect of increased cultural diversity in consumption goods.

The paper is structured as follows. In Section 2 we introduce our dataset and some stylized facts as regards migrant diversity in The Netherlands. Section 3 presents the estimation results for the impact of cultural diversity on equilibrium housing prices and wages across cities. In Section 4 we

\footnotetext{
3 Let us note that in terms of the wage effect our results differ from Ottaviano and Peri (2006) in that our results are more sensitive to the relative attractiveness of the local labour market as well as the sample size. More details and discussion is provided in Sections 3 and 4.
} 
show how and to what extent these results are influenced by spatial sorting of workers and home owners. Section 5 summarizes and concludes.

\section{Data and stylized facts}

The analysis in this paper is based on a newly constructed dataset that consists of data of individual home owners who are simultaneously identified as workers, and matches data on local labor and housing markets to data on individual firm and house characteristics, and detailed amenity data from various micro-datasets in the Netherlands over a period of ten years (1999-2008). We are thus able to follow an individual in the labor and housing market over time.

House-transaction data are provided by the Dutch Association of Real Estate Agencies (NVM), and cover roughly $50-70 \%$ of all residential houses sold in the Netherlands and includes information on the transaction date, transaction price, dwelling characteristics, and location. Individual data on workers and firms are provided by Statistics Netherlands (CBS). The worker data includes information on age, country of birth, country of birth of both parents, gender, residential location and the type of household. Individual firm data includes information on location, productivity statistics, individual employees, and wage per employee. Merging the housing, residential and firm data thus identifies the home owner, and the home owner's socio-economic characteristics like wage, education, firm and sector of employment, age, and country of birth. The amenity data are provided by CBS, the Real-Estate Monitor ('Vastgoed monitor', i.e. real estate monitor), the Ministry of Education (school data), and the Ministry of Internal Affairs (Leefbaarometer, i.e. quality of living index). Amenity data about the residential location include information on restaurants per nationality of the kitchen, (foreign) shops, elementary schools per religious denomination, cultural heritage, and a quality of living index. More details, including a description of data cleaning and processing, are provided in Annex 1 to this paper.

In order to identify sorting, productivity and amenity effects in the housing and labor market, we need individuals to appear at least twice in our 10 year dataset and we need enough individual 
observations per city in both the housing and labor market, i.e. enough home owners working in a city and moving into a city. In our final dataset we have 61,738 individual workers/home owners accounting for 126,959 observations over the 10 year period of the sample. The minimum threshold for the number of observations for each city in a given year is 10 due to confidentiality requirements for the use of micro data. Too few observations per city per year would also seriously weaken the robustness of our results. Additionally, we need enough observations for each of the 15 sectors we use in the labor market, and for the 21 housing types we use in the housing market. These conditions are easily met for larger cities, but not for all smaller and less urban cities. Therefore our analysis encompasses 176 out of the 443 municipalities in the Netherlands, covering $70 \%$ of the total population in the Netherlands. ${ }^{4}$

The main variable of interest in this research is cultural diversity. Cultural diversity can be measured in numerous ways (cf. Beugelsdijk and Maseland 2010). In this study we interpret cultural diversity in terms of migrant diversity, which we define by the country of birth of the parents of an individual resident. More specifically, we identify an individual as a migrant when at least one of her parents is born abroad, and the culture is determined by the country of birth of the mother, except when the mother is Dutch, in which case the country of birth of the father determines her culture. In other words, this definition encompasses first and second generation migrants as someone's culture is largely determined by her parents' culture. This definition is in line with standard practice in the Netherlands, and also accords with the popular practice in The Netherlands to consider second generation migrants still very much as foreign residents. ${ }^{5}$

\footnotetext{
${ }^{4}$ Table 2a in Annex 2 gives an overview of the number of municipalities per population size included in our analysis. The municipalities left out of the analysis are less urbanized, and they are at the lower end of the ethnic diversity index. Consequently, their exclusion from our sample will not prevent generalization of our results. Our spatial unit of analysis is the municipality which we call city throughout the text.

${ }^{5}$ This of course contrasts the situation in large parts of the US. By way of robustness check we have also conducted the analysis for average wages and housing prices using the first generation migrants only. Results in the housing market show that the estimated coefficient of diversity is somewhat larger when using this definition. In the labor market, the overall results are similar when using the $1^{\text {st }}$ generation definition, except that the effect of diversity is negative in models I and II of the all-cities sample. Details are available upon request.
} 
To calculate diversity among migrants we use an index that comprises all residents of a municipality (city), as the principal spatial observation unit in this study. The cultural diversity index for municipalities shows the probability that two randomly selected residents in a municipality are from different cultural groups. The index is defined as:

$$
\operatorname{div}_{c, t}=1-\sum_{i=1}^{M}\left(E_{i, t}^{c}\right)^{2}
$$

where $E_{i, t}^{c}$ is the share of people from cultural group $i$ among the residents of municipality $c$ in year $t$. An index value of 0 indicates that everyone living in a municipality belongs to the same cultural group, whereas all belong to a different cultural group when its value is 1 . In the literature this index is frequently used (see, for example, Ottaviano and Peri 2005,2006 ) because it takes into account both cultural 'richness' (i.e. the number of groups) and cultural 'diversity' (i.e. the distribution across group). Given the high correlation between the share of foreigners and the diversity index when calculated including the natives as a group, we also calculated the index for diversity among migrants only.

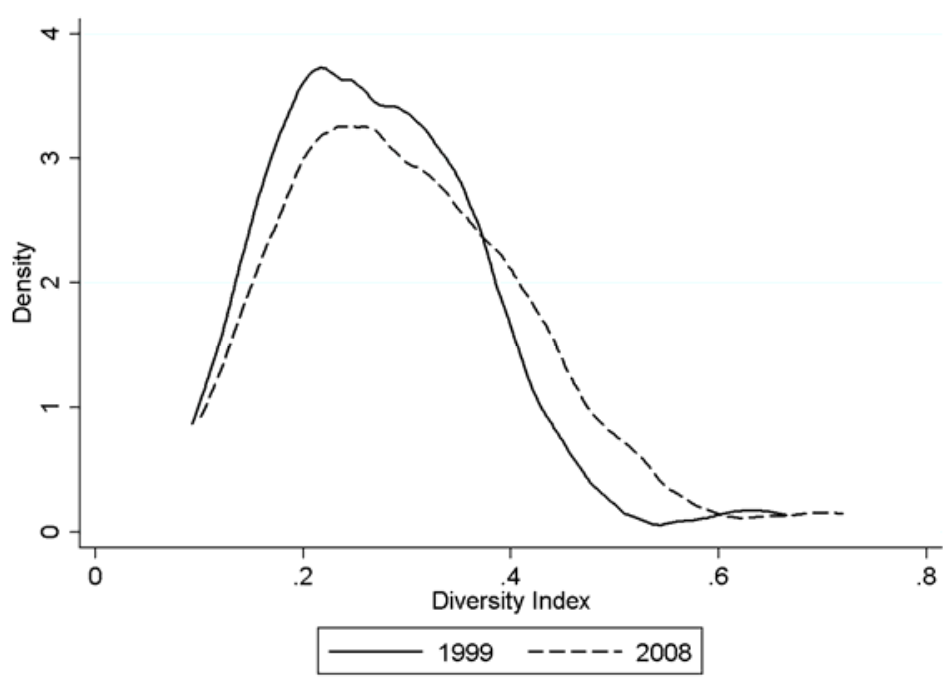

Figure 1: Distribution of diversity index per municipality in 1999 and 2008.

Source: own calculations based on CBS/GBA

Figure 1 gives the distribution across municipalities of the cultural diversity of migrants in 1999 and 2008. From the figure it can be seen that the right tail of the distribution has become 
fatter, indicating that municipalities have become more diverse in these 10 years, and the number of municipalities with lower diversity has decreased. Table 1 shows that the diversity in the four largest cities (all located in the densely populated Western part of the country called Randstad) has increased about $10 \%$, which is lower than the national average increase in diversity of almost $13 \%$ between 1999 and 2008. The change in the share of migrants and the diversity index in the biggest cities in the Netherlands has thus not diverted much from the rest of the country, as these cities where more diverse already in 1999. The diversity index among migrants shows that the Netherlands has people from many countries. The national increase in foreign share has been almost $18 \%$ as compared to $15 \%$ in the four biggest Randstad cities. This increase in foreign share is thus partly caused by an increase in first generation migrants, and partly caused by first generation migrants in the Netherlands getting children. This latter effect only partly influences the diversity index as it does not increase the number of ethnic groups, but only influences the distribution across groups.

Table 1: Share of migrants and diversity in 1999 and 2008

\begin{tabular}{|c|c|c|c|c|c|c|c|}
\hline \multicolumn{4}{|c|}{1999} & \multicolumn{4}{|c|}{2008} \\
\hline City (Area) & $\begin{array}{l}\text { Share of } \\
\text { migrants }\end{array}$ & $\begin{array}{l}\text { Diversity } \\
\text { index }\end{array}$ & $\begin{array}{l}\text { Diversity } \\
\text { among } \\
\text { migrants }\end{array}$ & City (Area) & $\begin{array}{l}\text { Share of } \\
\text { migrants }\end{array}$ & $\begin{array}{l}\text { Diversity } \\
\text { index }\end{array}$ & $\begin{array}{l}\text { Diversity } \\
\text { among } \\
\text { migrants }\end{array}$ \\
\hline Utrecht & 0.28 & 0.47 & 0.87 & Utrecht & 0.32 & 0.51 & 0.88 \\
\hline Rotterdam & 0.39 & 0.61 & 0.89 & Rotterdam & 0.46 & 0.69 & 0.90 \\
\hline The Hague & 0.39 & 0.62 & 0.89 & The Hague & 0.46 & 0.69 & 0.91 \\
\hline Amsterdam & 0.44 & 0.67 & 0.90 & Amsterdam & 0.49 & 0.72 & 0.91 \\
\hline Netherlands & 0.17 & 0.31 & 0.93 & Netherlands & 0.20 & 0.35 & 0.94 \\
\hline
\end{tabular}

Source: own calculations based on CBS/GBA 


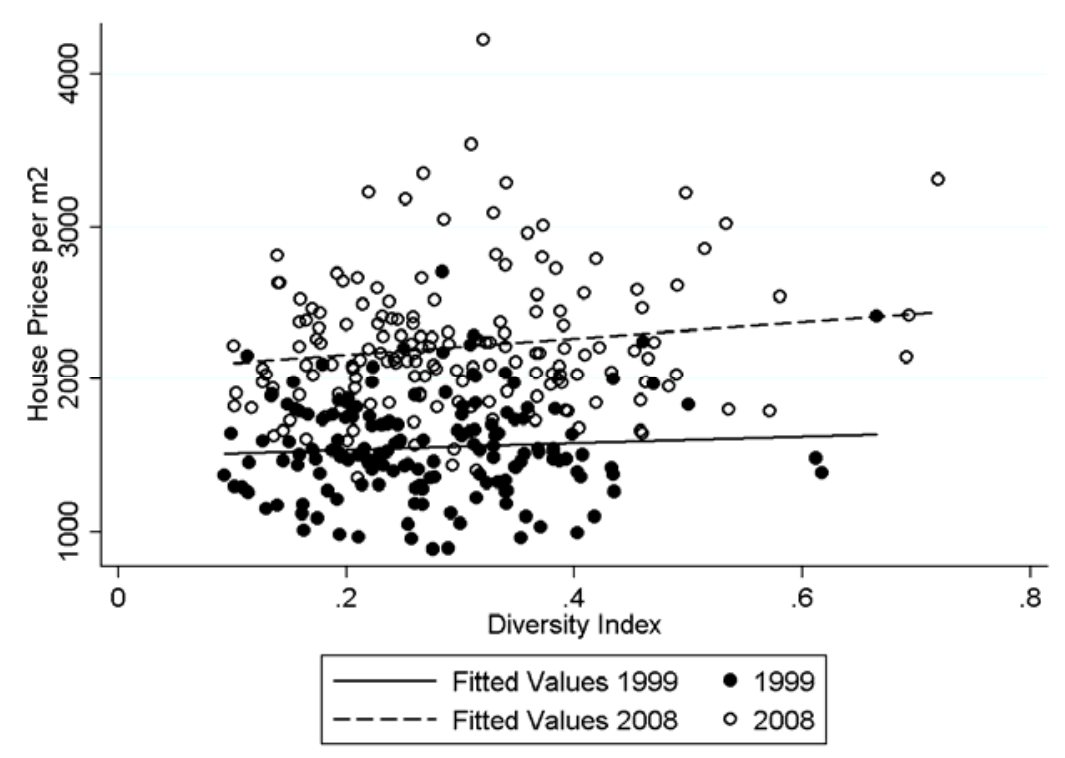

Figure 2: Correlation migrant diversity and average housing prices per square meter in 1999 and 2008 on the municipality level

Source: own calculations based on CBS/GBA and NVM-data

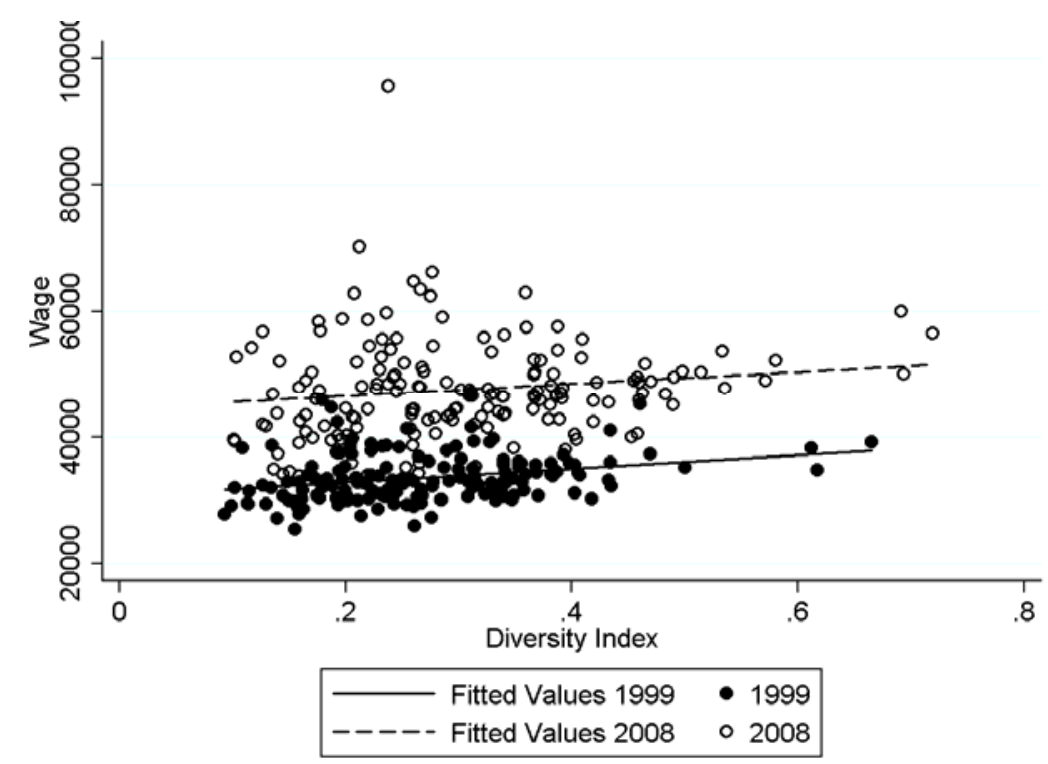

Figure 3: Correlation migrant diversity and average wages in 1999 and 2008 on the municipality level

Source: own calculations based on CBS/GBA and CBS/SSB

Figures 2 and 3 show that the correlation between migrant diversity and average wages and housing prices in municipalities in 1999 and 2008 is positive, but small. Also, Figures 2 and 3 suggest 
that the correlation has increased over time in the housing market and has remained roughly the same in the labor market.

\section{The average economic value of cultural diversity}

Following Ottaviano and Peri (2006), in the first part of our analysis we estimate a multi-city model of average production and average consumption to assess the economic value of cultural diversity that the foreign born bring to each city in The Netherlands. In short, the model deals with interactions between the labor and housing market by estimating average wage and average housing price differentials parallel in a Roback-like equilibrium model (Roback 1982). The model allows assessing the impact of cultural diversity through its localized effect on both the productivity of firms and the utility of consumers. Given the interdependences of the housing and labor market, a strong feature of this equilibrium framework is that it considers the impact of diversity on both the housing and labor market, in contrast to estimates derived from a partial analysis. As noted before, a serious drawback of this approach, however, is that it assumes identical effects of cultural diversity on utility across agents and firms. In other words, it assumes workers and home owners to be homogenous and consequently does not allow for spatial sorting. In Section 4 we relax this assumption in order to evaluate to what extent the impact of cultural diversity on equilibrium housing prices and wages is influenced by various sorting effects.

The basic Roback model (1982) is a model with many cities that vary according to the quantity of an amenity. Both the indirect utility and the production are a function of wages, rents, and amenities. Following Ottaviano and Peri (2006), migrant diversity is the key explanatory variable in both the wage and housing price equation. Utility for a worker belonging to group $i$ in city $c$ is defined as:

$$
U_{i, c}=A_{U}\left(d_{c}\right) H_{i, c}^{1-\mu} Y_{i, c}^{\mu}
$$


with $H_{i, c}$ and $Y_{i, c}$ the land and good consumption, $A_{U}\left(d_{c}\right)$ the utility effect from local diversity $d_{c}$ and $0<\mu<1$. Diversity enters [2] as an exogenous variable and can either be positive or negative depending on the first derivative of $A_{U}\left(d_{c}\right)$. The positive effect on utility might be due to, for example, the positive utility derived from product variety. The production function of firm $j$ in city $c$ is given by:

$$
Y_{j, c}=A_{Y}\left(d_{c}\right) H_{j, c}^{1-\alpha} L_{j, c}^{\alpha}
$$

with $H_{j, c}$ and $L_{j, c}$ the land and labor inputs, $A_{Y}\left(d_{c}\right)$ the productivity effect from local diversity $d_{c}$ and $0<\alpha<1$. The productivity effect enters [3] as a shift in total factor productivity and can be either positive or negative depending on, for example, human capital externalities or complementarities between different cultural groups. ${ }^{6}$ Comparing $A_{Y}$ and $A_{U}$ gives the prevailing effect of diversity on the economy. Empirical implementation of this idea, after solving the model, leads to the following general wage equation to be estimated (see Ottaviano and Peri 2006):

$$
\ln \left(\bar{w}_{c, t}\right)=\beta_{1}\left(\operatorname{div}_{c, t}\right)+\beta_{2}\left(\text { controls }_{c, t}\right)+\varepsilon_{c}+\varepsilon_{c, t}
$$

with the average wage $\bar{w}$ in city $c$ in year $t$ as a function of the diversity in city $c$ in year $t$, with $t=1999, \ldots \ldots, 2008$, control variables, a city fixed effect $\varepsilon_{c}$, and an error term $\varepsilon_{c, t}$. The share of high educated in the city and the natural logarithm of the number of jobs reachable within 45 minutes commuting time (indicator for density of the labor market) are used as control variables. The general housing price equation to be estimated within this framework equals:

$$
\ln \left(\bar{r}_{c, t}\right)=\gamma_{1}\left(\text { div }_{c, t}\right)+\gamma_{2}\left(\text { controls }_{c, t}\right)+\varepsilon_{c}+\varepsilon_{c, t}
$$

\footnotetext{
${ }^{6}$ See Ottaviano and Peri (2006) for the full description and derivation of the model.
} 
with the average housing price per square meter $\bar{r}$ in city $c$ in year $t$ as a function of the diversity in city $c$ in year $t$, with $t=1999, \ldots \ldots, 2008$, control variables, a city fixed effect $\varepsilon_{c}$, and an error term $\varepsilon_{c, t}$. We use the natural logarithm of the income per capita in the city (indicator for wealth) ${ }^{7}$ as a control variable.

The spatial equilibrium-framework implies that workers cannot reap a housing market premium in lower density areas. Using MSA data for the United States, Ottaviano and Peri (2006) assume that agents live and work in the same city, i.e. no commuting is allowed for. We think this is too strong an assumption in our study, since we use municipality data for a small country like the Netherlands. In order to still be able to characterize wage and rent differences as functions of the amenity in the equilibrium situation (with a given distribution of firms and workers across cities), we adjusted wages such that they are net of commuting-time costs. ${ }^{8}$ Consequently, equations [4] and [5] are estimated with the average wages and housing prices based on the individual home owner's wage and house price in our dataset. The model is estimated for different spatial levels and selections of cities in The Netherlands. We present the results for the Nuts-3 level, the city level, a sample excluding the 25 largest cities and a sample including only the 25 largest cities. ${ }^{9}$ Migrants traditionally tend to locate in the most urban areas so these 25 municipalities are likely to constitute the largest diversity within the Netherlands.

Table 2 and 3 give the results for the basic OLS regression with city fixed-effects. ${ }^{10}$ For the Netherlands we roughly reproduce the key finding that Ottaviano and Peri (2006) present for U.S. cities, in that diversity has a positive effect on average wages and housing prices across cities. More precisely, we find that an increase in the cultural diversity of the population on average positively

\footnotetext{
${ }^{7}$ We have also used population density as a control variable to account for demand factors in the housing market, but this variable is either insignificant or slightly negatively significant. The overall conclusions are thus not affected by excluding this variable.

${ }^{8}$ See the data description in Annex 1 . We have also estimated this model without a correction for commuting costs, but with a sample selection of only male, native workers between ages 40 and 60 who do not commute, i.e. live and work in the same municipality or Nuts3-level. With this much smaller sample the results point in the same direction as with the larger sample of which we present the results in this paper.

${ }^{9}$ See Table $2 \mathrm{a}$ in Annex 2 for an overview of the city-size distribution across the samples.

${ }^{10}$ We have an unbalanced panel as we do not have sufficient observations for all 10 years for all 176 municipalities.
} 
Table 2: Results basic wage and rent OLS regressions - average wages and rents

\begin{tabular}{|c|c|c|c|c|c|c|c|c|c|c|}
\hline \multirow[b]{3}{*}{ Variables } & \multicolumn{5}{|c|}{ Municipalities } & \multicolumn{5}{|c|}{ NUTS-3 level } \\
\hline & \multicolumn{3}{|c|}{ Ln(wage) } & \multicolumn{2}{|c|}{$\begin{array}{l}\text { Ln(housing price } \\
\text { (per } \mathrm{m} 2))\end{array}$} & \multicolumn{3}{|c|}{ Ln(wage) } & \multicolumn{2}{|c|}{$\operatorname{Ln}($ housing price (per $\mathrm{m} 2)$} \\
\hline & Model I & Model II & Model III & Model I & Model II & Model I & Model II & Model II & Model I & Model II \\
\hline \multirow[t]{2}{*}{ Diversity index } & $0.55^{*}$ & 0.01 & & $3.07 * * *$ & & 0.37 & 0.35 & & $7.00 * * *$ & \\
\hline & $(0.32)$ & $(0.31)$ & & $(0.37)$ & & $(0.49)$ & $(0.50)$ & & $(0.78)$ & \\
\hline \multirow[t]{2}{*}{ Share of migrants } & & & 0.57 & & $3.07 * * *$ & & & 0.43 & & $6.41 * * *$ \\
\hline & & & $(0.48)$ & & $(0.37)$ & & & $(0.74)$ & & $(0.82)$ \\
\hline Diversity index among & & & $1.57 * * *$ & & $5.47 * * *$ & & & 0.40 & & $8.40 * * *$ \\
\hline migrants & & & $(0.52)$ & & $(0.57)$ & & & $(0.54)$ & & $(1.38)$ \\
\hline \multirow[t]{2}{*}{ In(jobs in 45 minutes) } & & $1.25^{* * *}$ & & & & & 0.01 & & & \\
\hline & & $(0.16)$ & & & & & $(0.05)$ & & & \\
\hline \multirow[t]{2}{*}{ Share high educated } & $6.80 * * *$ & $5.15^{* * *}$ & $6.38 * * *$ & & & $7.75 * * *$ & $7.73 * * *$ & $7.63 * * *$ & & \\
\hline & $(0.40)$ & $(0.39)$ & $(0.42)$ & & & $(0.62)$ & $(0.61)$ & $(0.71)$ & & \\
\hline \multirow[t]{2}{*}{ In(income_capita) } & & & & $1.09 * * *$ & $0.86 * * *$ & & & & $1.22 * * *$ & $0.55^{* * *}$ \\
\hline & & & & $(0.06)$ & $(0.05)$ & & & & $(0.32)$ & $(0.19)$ \\
\hline$R^{2}$ & 0.43 & 0.46 & 0.43 & 0.61 & 0.67 & 0.70 & 0.70 & 0.70 & 0.66 & 0.78 \\
\hline City fixed-effects & yes & Yes & Yes & yes & yes & yes & yes & yes & yes & yes \\
\hline No. of obs. Units & 176 & 176 & 176 & 176 & 176 & 38 & 38 & 38 & 38 & 38 \\
\hline
\end{tabular}

$* *$ significant at $1 \%, * *$ at $5 \%, *$ at $10 \%$. Heteroskedasticity-robust standard error in parentheses.

Source: own calculations based on CBS(GBA, SSB), NVM, ABF-Real Estate monitor. 
Table 3: Results basic wage and rent OLS regressions - average wages and rents

\begin{tabular}{|c|c|c|c|c|c|c|c|c|c|c|}
\hline \multirow[b]{3}{*}{ Variables } & \multicolumn{5}{|c|}{ Municipalities excl. 25 largest cities } & \multicolumn{5}{|c|}{25 largest cities } \\
\hline & \multicolumn{3}{|c|}{ Ln(wage) } & \multicolumn{2}{|c|}{ Ln(housing price (per m2)) } & \multicolumn{3}{|c|}{ Ln(wage) } & \multicolumn{2}{|c|}{ Ln(housing price (per $\mathrm{m} 2$ )) } \\
\hline & Model I & Model II & Model III & Model I & Model II & Model I & Model II & Model II & Model I & Model II \\
\hline \multirow[t]{2}{*}{ Diversity index } & 0.48 & -0.07 & & $3.19 * * *$ & & $1.26 * * *$ & $0.89 * *$ & & $2.96 * * *$ & \\
\hline & $(0.40)$ & $(0.37)$ & & $(0.43)$ & & $(0.26)$ & $(0.33)$ & & $(0.83)$ & \\
\hline \multirow[t]{2}{*}{ Share of migrants } & & & 0.42 & & $3.30 * * *$ & & & $1.58 * * *$ & & $2.92 * * *$ \\
\hline & & & $(0.64)$ & & $(0.51)$ & & & $(0.41)$ & & $(0.45)$ \\
\hline Diversity index among & & & $1.50 * *$ & & $5.15^{* * *}$ & & & $1.75^{* *}$ & & $7.09 * * *$ \\
\hline migrants & & & $(0.60)$ & & $(0.63)$ & & & $(0.77)$ & & $(1.48)$ \\
\hline \multirow[t]{2}{*}{ In(jobs in 45 minutes) } & & $1.33 * * *$ & & & & & $0.54 * *$ & & & \\
\hline & & $(0.18)$ & & & & & $(0.23)$ & & & \\
\hline \multirow[t]{2}{*}{ Share high educated } & $7.10^{* * *}$ & $5.15^{* * *}$ & $6.66 * * *$ & & & $5.28 * * *$ & $4.92 * * *$ & $4.91 * * *$ & & \\
\hline & $(0.45)$ & $(0.45)$ & $(0.48)$ & & & $(0.55)$ & $(0.57)$ & $(0.59)$ & & \\
\hline \multirow[t]{2}{*}{ In(income_capita) } & & & & $1.13^{* * *}$ & $0.90 * * *$ & & & & $0.89 * * *$ & $0.61 * * *$ \\
\hline & & & & $(0.06)$ & $(0.05)$ & & & & $(0.16)$ & $(0.08)$ \\
\hline $\mathrm{R}^{2}$ & 0.40 & 0.43 & 0.40 & 0.59 & 0.65 & 0.76 & 0.76 & 0.76 & 0.78 & 0.85 \\
\hline City fixed-effects & Yes & yes & Yes & yes & yes & yes & yes & yes & yes & yes \\
\hline No. of obs. Units & 151 & 151 & 151 & 151 & 151 & 25 & 25 & 25 & 25 & 25 \\
\hline
\end{tabular}

$* * *$ significant at $1 \%, * *$ at $5 \%, *$ at $10 \%$. Heteroskedasticity-robust standard error in parentheses.

Source: own calculations based on CBS(GBA, SSB), NVM, ABF-Real Estate monitor. 
affects wages and housing prices in the largest and most densely populated cities in the Netherlands between 1999 and 2008.

In the labor market we find a positive effect of diversity on the city level which is mostly driven by the positive effect that diversity has in the larger cities (see Table 3). On the Nuts-3 level (Table 2), we do not find a significant effect. The share of high educated is positive and significant in all models across all city selections. When including the number of jobs one can reach within 45 minutes of commuting (model II), the positive effect of diversity only remains significant for the largest cities. This signals the effect of labor market density, i.e. agglomeration, on wages and also indicates that sorting might be important. At the Nuts-3 level labor market density is not significant, which is somewhat surprising because the Nuts-3 level roughly indicates a labor market area. On average an increase of the diversity index of 0.1 would increase wages by $5.5 \%$. In the largest cities, an increase in the diversity index of 0.1 , would increase wages by $12.6 \%$, and this effect decreases to 8.9\% when including the density of the labor market in model II. Table 1 shows that between 1999 and 2008 the diversity index in the four largest cities of The Netherlands has increased on average with about 0.06 , thus roughly corresponding with a $6 \%$ wage increase. Model III differentiates between the share of migrants and the diversity among migrants. Only for all cities and the largest 25 cities is the diversity index among migrants significant and positive in the labor market. In sum, our results indicate that the density of the labor market and the share of high educated are among the main drivers for wage disparities in the Netherlands. These results are in line with recent research on wage disparities in the Netherlands (De Groot et al. 2010, Marlet, 2009).

Regarding the housing market, Table 2 and 3 show a positive effect of cultural diversity at all spatial levels and for all municipality selections - an effect that is more pronounced as compared to the labor market. On average for all cities, an increase in the diversity index of 0.1 increases housing prices per square meter by about $31 \%$, a result that proves to be fairly stable across the different samples (32\% for all cities excl. 25 largest cities, and 30\% for the 25 largest cities). The share of migrants and the diversity among migrants (model II) are both significant and positive for all samples. 
Income per capita is also significant and positive in all models indicating that wealthier municipalities have higher housing prices per square meter. So both in the labor and the housing market we find positive coefficients for cultural diversity and the share of migrants, indicating that the overall effect of an increase in cultural diversity will be positive.

In these estimations, it may be that diversity and the share of migrants are endogenous to average wages and average housing prices ${ }^{11}$. Migrants may cause higher wages because they increase productivity, or conversely migrants can be drawn to more productive places i.e. to places with higher wages. Similarly, the presence of migrants may increase housing prices because cultural diversity is considered a positive amenity, or conversely migrants are drawn to places with higher housing prices because they signal more favourable location characteristics. We have no reason to assume that the diversity among migrants itself is endogenous. To assess the causal relationship between diversity on the one hand and wages and housing prices on the other hand, we therefore estimate a 2SLS model with the diversity index and share of migrants instrumented. In doing so, we use the shift-share methodology applied by, among others, Card (2001), and Saiz (2003). This methodology builds on the assumption that the best predictor of future migrants' location choices are past migrants' location choices; because new immigrants often settle where other immigrants that share the same culture already reside, the share of migrants with a certain culture in a municipality in the past is a good predictor of where new migrants with that culture will locate in the future (see Bartel 1989).

We use the share of migrants from a culture (i.e. country of birth of the parents) in a municipality in 1995 and predict the share of that culture in that municipality between 1999 and 2008 by allocating the national growth rate of that culture to the initial municipality level as is given in [6]:

\footnotetext{
${ }^{11}$ The 2SLS estimations indeed show that the diversity index and the share of foreigners is endogenous to average housing prices, which makes the causality inference difficult, but less so to average wages. This could indicate that the wage level is less of a pull factor in the labour market for migrants. We would argue that perhaps employment opportunities and network effects are more important. This induces a different problem in the analysis, i.e. multicollinearity. We ignore this for now, but will address this issue in the next step of our analysis.
} 


$$
\widehat{E_{l, t}^{c}}=E_{i, t=1995}^{c}\left[1+g_{i, 1995-t}\right]
$$

with $\widehat{E_{l, t}^{c}}$ the estimated share of migrants with culture $i$ in city $c$ in year $t=1999, \ldots, 2008, E_{i, t=1995}^{c}$ the share of migrants with culture $i$ in city $c$ in 1995 , and $g_{i, 1995-t}$ the national growth rate of the share of culture $i$ between 1995 and year $t=1999, \ldots, 2008$. Additionally we can estimate the diversity index and the share of migrants. Since we use the second generation definition of migrants, the time frame that we use to instrument diversity is limited to one generation and a five year time lag is sufficient. As a second instrument we use the shift-share methodology to instrument the population density in a municipality. Migrants tend to locate in denser areas for, among others, labor market reasons, and the population density in an area is therefore a good indicator for the share of migrants the area will attract. Since these dynamics will be endogenous only for longer time lags, we use the population in 1972 as the base for population growth per city as in [6]. The identification tests show that the estimated population is a good instrument for both foreign share and diversity.

Table 4a. IV estimates, FE estimation for average wages and housing prices.

\begin{tabular}{|c|c|c|c|}
\hline \multirow[b]{3}{*}{ Variables } & \multicolumn{3}{|c|}{ Municipalities } \\
\hline & \multirow{2}{*}{$\begin{array}{c}\text { Ln(wage) } \\
\text { Model I }\end{array}$} & \multicolumn{2}{|c|}{ Ln(housing prices (per m2)) } \\
\hline & & Model I & Model II \\
\hline \multirow[t]{2}{*}{ Diversity index } & $1.79 * * *$ & $5.04 * * *$ & \\
\hline & $(0.33)$ & $(0.25)$ & \\
\hline \multirow[t]{2}{*}{ Foreign share } & & & $4.11 * * *$ \\
\hline & & & $(0.28)$ \\
\hline \multirow[t]{2}{*}{ Diversity index among migrants } & & & $5.07 * * *$ \\
\hline & & & $(0.37)$ \\
\hline \multicolumn{4}{|l|}{ In(jobs in 45 minutes) } \\
\hline \multirow[t]{2}{*}{ In(income_capita) } & & $0.80 * * *$ & $0.79 * * *$ \\
\hline & & $(0.05)$ & $(0.28)$ \\
\hline \multirow[t]{2}{*}{ Share of high educated } & $5.80 * * *$ & & \\
\hline & $(0.39)$ & & \\
\hline $\mathrm{R}^{2}$ & 0.42 & 0.57 & 0.67 \\
\hline Partial $R^{2}$ & 0.74 & 0.80 & 0.84 \\
\hline Hansen J statistic & 3.582 & 1.735 & 0.1 \\
\hline (p-value) & $(0.058)$ & $(0.19)$ & $(0.75)$ \\
\hline
\end{tabular}


Table $4 b$. IV estimates, FE estimation for average wages and housing prices.

\begin{tabular}{|c|c|c|c|c|c|}
\hline \multirow[b]{3}{*}{ Variables } & \multicolumn{5}{|c|}{25 largest Municipalities } \\
\hline & \multicolumn{3}{|c|}{ Ln(wage) } & \multicolumn{2}{|c|}{ Ln(housing prices (per m2)) } \\
\hline & Model I & Model II & Model III & Model I & Model II \\
\hline \multirow[t]{2}{*}{ Diversity index } & $1.40 * * *$ & $0.85^{* *}$ & & $3.84 * * *$ & \\
\hline & $(0.38) \#$ & $(0.38) \#$ & & $(0.43)$ & \\
\hline \multirow[t]{2}{*}{ Foreign share } & & & $1.53 * * *$ & & $3.35 * * *$ \\
\hline & & & $(0.50) \#$ & & $(0.34)$ \\
\hline Diversity index & & & $1.75^{* * *}$ & & $6.94 * * *$ \\
\hline among migrants & & & $(0.65)$ & & $(0.84)$ \\
\hline \multirow[t]{2}{*}{ In(jobs in 45 minutes) } & & $0.55^{* *}$ & & & \\
\hline & & $(0.23)$ & & & \\
\hline \multirow[t]{2}{*}{ In(income_capita) } & & & & $0.70 * * *$ & $0.55^{* * *}$ \\
\hline & & & & $(0.1)$ & $(0.07)$ \\
\hline Share of high & $5.13 * * *$ & $4.95 * * *$ & $4.94 * * *$ & & \\
\hline educated & $(0.51)$ & $(0.55)$ & $(0.55)$ & & \\
\hline$R^{2}$ & 0.76 & 0.76 & 0.76 & 0.77 & 0.85 \\
\hline Partial $R^{2}$ & 0.86 & 0.85 & 0.84 & 0.91 & 0.88 \\
\hline Hansen J statistic & 0.769 & 0.795 & 2.419 & 0.000 & 0.39 \\
\hline (p-value) & $(0.38)$ & $(0.37)$ & $(0.12)$ & (0.99) & $(0.53)$ \\
\hline
\end{tabular}

Table $4 \mathrm{a}$ and $4 \mathrm{~b}$ give the instrumental variable (IV) estimation results for the 2 SLS model with city fixed-effects. The used instruments are exogenous and jointly pass the overidentification test in all models except model I for the labor market in Table 4a. For this model, we are thus not confident that our results in the labor market can be interpreted as cultural diversity causing higher wages. For all other models we can conclude that the correlation and causality we have found in the fixed-effect estimation is correct. We even find higher values for cultural diversity in Table 4b.

To summarize, cultural diversity on average has a positive impact on equilibrium housing prices and wages through its localized effect on both the productivity of firms and the utility of consumers. This is especially true for the larger cities while in the smaller cities we do not find an effect of migrant diversity on average wages. As argued several times before, our analysis implicitly assumed homogeneous preferences and abilities for all home owners. Apart from contradicting existing heterogeneity among individuals, this assumption prevents a thorough analysis of what 
exactly underlies the observed positive effect of cultural diversity. When relaxing these assumptions and thus controlling for observed and unobserved characteristics of individual home owners in interdependent labor and housing markets, it is possible to take into account the heterogeneity of individual agents. This allows us to identify the role of spatial sorting in explaining spatial disparities in wages and housing prices. Moreover, in this way it is possible to subsequently explore to what extent the remaining variation in wages and housing prices across cities can be explained from interactions-based productivity effects and local amenities, in relation to cultural diversity. This is what we aim to do in the next section.

\section{Spatial sorting and the economic value of cultural diversity}

In order to identify the role of sorting in explaining spatial wage- and housing-price disparities, we now take into account the (unobserved) preferences and characteristics of home owners in interdependent labor and housing markets. This requires to control for a range of local factors that may impact individual wages and housing prices, including endowments, interactions, and stock of worker's skills in the two interrelated markets. In short, we need to change the equilibrium model developed in Section 3 into a worker fixed-effect model with municipality-specific time trends and sector effects in the labor market, and a home owner fixed-effect model with municipality-specific time trends and house characteristics in the housing market. This would mean estimating a model with an unmanageable large number of fixed effects (176 cities times 14 sectors times 10 years and 61,738 worker/home owner fixed effects). As mentioned before, for this reason we adopt the approach developed by Combes et al. (2008) to account for spatial sorting in the labor market, and slightly modify their approach in that we apply it to both the labor market and the housing market, accounting for unobserved interactions in these markets. The latter implies that we are able to present the explanatory power of the aforementioned various local factors that may impact housing price and wage disparities across space. 
More precisely, the approach taken is a two-step approach. In the first stage, individual fixedeffects are estimated using the within $^{12}$ estimator in a simple OLS regression for the wage and housing price equation. All variables are therefore centred to their mean for each individual. ${ }^{13}$ This first stage accounts for sorting in the labor and housing market, and gives us an estimated remaining area-year effect for both markets. Then, in the second stage, the value of amenities is estimated using the estimated coefficients for the area-year fixed effects from the first stage.

In the first stage we estimate the following wage equation: ${ }^{14}$

$$
\ln \left(w_{i, t}\right)=\beta_{1 c(i, t), t}+\gamma_{k(i, t)}+\delta_{i}+X_{i, t} \varphi+\tilde{X} \gamma_{k(i, t)}+\epsilon_{i, t}
$$

with $w_{i, t}$ the wage of home owner $i$ in time $t, \beta_{1 c(i, t), t}$ the area-year fixed effect for municipality $c$ in year $t, \gamma_{k(i, t)}$ the sector fixed-effect ${ }^{15}$ for sector $k, \delta_{i}$ the individual fixed effect of the home owner in the labor market, $X_{i, t} \varphi$ time-varying individual characteristics, $\tilde{X} \gamma_{k(i, t)}$ a sector-age effect, and $\epsilon_{i, t}$ the error term. We include the deviation of the average sector age from the average working population age of our sample to account for systematic sector-composition effects. The idea here is that an area might have a higher share of young workers because the area has a relatively high concentration of a sector that attracts young workers, like, for example the ICT-sector. We use age of the home owner as the time-varying individual fixed effect. For identification reasons, we set the agricultural sector, and a municipality in 1999 to zero.

As mentioned before, in contrast to Combes et al. (2008) we not only take into account the labor market but also the housing market, in search for spatial housing prices disparities. The housing price equation we estimate resembles the wage equation:

\footnotetext{
${ }^{12}$ According to the Frisch-Waugh Lovell theorem (Baltagi 1996).

${ }^{13}$ We have decreased the number of periods in our data set from 10 to 5 years by setting 1 time period in the analysis to 2 years, as the data set would still be too large for our software capacity. This allows us to estimate the model without loss of observations. Variables that are initially measured at a 1 year interval, are then calculated as averages over the 2 year period. This will somewhat decrease the variability within variables in our dataset.

${ }^{14}$ See Combes et al. (2008) for a detailed description and derivation of the model and estimations.

${ }^{15}$ We assume that the temporal effect within industries is captured in the area-year fixed effect.
} 


$$
\ln \left(r_{i, t}\right)=\beta_{2 c(i, t), t}+H_{h(i, t)} \theta+\delta_{i}+X_{i, t} \varphi+\epsilon_{i, t}
$$

with $r_{i, t}$ the housing price per square metre of home owner $i$ in time $t, \beta_{2 c(i, t)}$ the area-year fixed effect for municipality $c, H_{h(i, t)} \theta$ a vector of house characteristics associated with the house fixedeffect, $\delta_{i}$ the individual fixed-effect of the home owner in the housing market, $X_{i, t} \varphi$ time-varying individual characteristics, and $\epsilon_{i, t}$ the error term. We use age of the home owner as the time-varying individual effect. The vector of housing characteristics contains the level of maintenance on the outside and inside, the type of house or apartment, and construction year of the house. For identification reasons, we set a house type and a municipality in 1999 to zero.

Following Combes et al. (2008) we present the results of the first step of our empirical strategy by showing the explanatory power of each variable. Therefore we calculate the standard deviation of each estimated effect and correlation of each estimated effect with, respectively, wages and housing prices. A high standard deviation in combination with a high correlation coefficient indicates a large explanatory power of that variable. The estimated effects are calculated by multiplying the estimated coefficients with the values for each observation. The individual fixedeffect is the mean prediction error of the regression. Table 5 a shows the effects for the wage equation and Table $5 b$ shows the effects for the housing price equation.

From Tables $5 a$ and $5 b$ it can be seen that individual effects are, by far, the principal determinant of wages and housing prices in the Netherlands. The unobserved individual fixed-effects account for the largest part of it, while the observable effect of age is smaller, but nevertheless still substantial. In addition, we find a moderate role of the sector effect in explaining wage variations in the Netherlands. In contrast, the area-year effect only explains a very small part of the variance in wages. The latter means that we do not find a large separate effect of the local area on wages, once we have controlled for individual characteristics of workers and sector. In the housing market, however, the local area plays a more prominent role. After having controlled for individual home- 
owner effects and to a lesser extent age, the area-year effect explains most of the variation in housing prices. In other words, house characteristics seem to explain only a small part of the housing price disparities across space.

Table 5a Summary statistics for the variance decomposition - estimation of equation [8]

\begin{tabular}{lrr}
\hline Effect & St. Dev. & Correlation with In(wage) \\
\hline Residuals & 0.15 & 0.37 \\
Individual effect & 0.37 & 0.89 \\
Age effect & 0.36 & 0.34 \\
Sector effect & 0.04 & 0.11 \\
Sector-age effect & 0.01 & -0.01 \\
Area-year effect & 0.04 & -0.07 \\
\hline Source: own calculations based on CBS (GBA, SSB) NVM, ABF-Real Estate monitor
\end{tabular}

Source: own calculations based on CBS (GBA, SSB), NVM, ABF-Real Estate monitor.

Table $5 b$ Summary statistics for the variance decomposition - estimation of equation [9]

\begin{tabular}{lrr}
\hline Effect & St. Dev. & Correlation with In(housing price per $\mathbf{~} 2$ ) \\
\hline Residuals & 0.13 & 0.43 \\
Individual effect & 0.25 & 0.82 \\
Age effect & 0.35 & 0.19 \\
Maintenance inside effect & 0.02 & 0.08 \\
Maintenance outside effect & 0.01 & 0.1 \\
Pre-1930 construction effect & 0.01 & 0.16 \\
House type effect & 0.05 & 0.28 \\
Area-year effect & 0.16 & 0.50 \\
\hline
\end{tabular}

Source: own calculations based on CBS (GBA), NVM, ABF-Real Estate monitor.

Table 6 Spatial wage and housing price disparities, 1999-2008 average

\begin{tabular}{lrrrr} 
& \multicolumn{2}{c}{ Wage } & \multicolumn{2}{c}{ Housing price } \\
\cline { 2 - 5 } Disparity measure & Mean wage & Net wage & Mean housing price & Net housing price \\
\hline (max - min)/min & 0.12 & 0.04 & 0.220 & 0.164 \\
(P90 - P10)/P10 & 0.03 & 0.01 & 0.074 & 0.054 \\
(P75 - P25)/P25 & 0.02 & 0.006 & 0.035 & 0.027 \\
Coefficient of variation & 0.01 & 0.005 & 0.03 & 0.02 \\
\hline
\end{tabular}

In order to further evaluate the importance of sorting on spatial wage and housing price disparities, we can compare the variations of, respectively, the mean wage and mean housing prices with the variations of the net wage and net housing prices. The net wage is the regional wage for an average worker in an average sector, and is calculated as the regional wage net of individual and sector effects. Likewise, the net house price is calculated as the regional house price net of home 
owner and dwelling effects. Comparing these with the real mean wages and housing prices then tells us to what extent disparities in wages and housing prices can be explained from, respectively, worker and sector effects, and home owner and dwelling effects. The results are listed in Table 6 and show that in the labour market, unobserved individual heterogeneity accounts for about 58 to $65 \%$ of spatial wage disparities. In the housing market, unobserved individual home-owner heterogeneity accounts for about 23 to $29 \%$ of spatial housing-price disparities. ${ }^{16}$

We continue our analysis by retrieving the estimated area fixed-effects from the housing price and wage equation ([8] and [9]), which are the rent and wage residuals, respectively. These residuals signal the "value" of local characteristics of either market net of worker, and sector, and house owner, and dwelling characteristics. In the labor market it can signal the productivity effect of amenities, agglomeration externalities, or some productivity effect of the housing market or the population composition. The local characteristics of the housing market consist of the local amenities, but can also be influenced by the attractiveness of the local labor market in terms of wage premiums or job density. ${ }^{17}$ These local wage and rent residuals can then be used in the final step of our analysis as dependent variables that are further explained by local characteristics of both markets. In this step we integrate both markets by including the wage residuals in explaining the disparities in housing market area effects and including the rent residuals in explaining the disparities in labor market area effects. This is done by estimating the following equations:

$$
\hat{\beta}_{1 c, t}=X_{c, t} \mu+I_{c, t} \gamma+\hat{\beta}_{2 c, t}+\theta_{t}+\epsilon_{c, t}
$$

\footnotetext{
${ }^{16}$ From table 6 it can be observed that disparities in the mean wage are relatively low. As noted before, this is partly due to low wage disparities in the Netherlands, and is it is likely also partly due to our sample selection of home owners who tend to be at the higher end of the wage distribution.

${ }^{17}$ Table 2B in Annex 2 lists the areas with the highest and lowest average area-year effects.
} 
with $\hat{\beta}_{1 c, t}$ the estimated area fixed-effect for area $a$ in year $t$ for the labor market, $\hat{\beta}_{2 c, t}$ the estimated area fixed-effect for area $a$ in year $t$ for the housing market, $X_{c, t} \mu$ a vector of migrantinduced amenities, $I_{c, t} \gamma$ a vector of other amenities, $\theta_{t}$ a time dummy, and $\epsilon_{c, t}$ or $\eta_{c, t}$ the error term. The other amenities include the presence of an historic city centre, the share of high educated, population density (in the labour market) and job density (in the housing market). Migrant amenities include the population diversity index and an index for product variety. Since we are interested in the effect of migrant diversity on the area effects, we focus on these explanatory variables. The results are presented in Table 7.

From this table it can be seen that - after having controlled for individual heterogeneity in the first step - cultural diversity has no statistically significant impact on the area effect in the labor market, but it does have a statistically significant negative impact on the area effect in the housing market (models I). In other words, we do not find evidence that cultural diversity has a separate effect on wages other than through worker and sector effects. This means that, for example, migrant-induced variations in supply shifts across education-experience groups (Borjas 2001, 2003; Card 1990, 2001; Card and Niardo 2000), intercultural frictions ('Babel effect') and Jacobs'-like productivity externalities (Jacobs 1969) are either very small and/or balance each other out. Also, it is worth to bear in mind that the local area-effect in the labor market itself is small (see Table 5a), which together enforces the conclusion that the effect of cultural diversity on the average wages across cities in The Netherlands are predominantly caused by sorting based on unobserved individual heterogeneity. In the housing market, however, the picture is different. Not only is the local areaeffect in the housing market relatively large (as compared to the labour market; see Table 5b), but cultural diversity has a separate significant impact on housing prices, i.e. other than through individual home owner and dwelling characteristics.

This result justifies a more detailed exploration of the housing market. We therefore enrich our basic equation (model I) by taking into account the potential effect of the variety of consumption goods, and quality of living at the municipality level. The restaurant indicator, that serves to account 
Table 7 OLS regression results for equation [10] and [11]

\begin{tabular}{|c|c|c|c|c|c|c|}
\hline \multirow[b]{2}{*}{ Variables } & \multicolumn{2}{|c|}{ Area-year effect (labor market) } & \multicolumn{4}{|c|}{ Area-year effect (housing market) } \\
\hline & \multicolumn{2}{|l|}{ Model I } & Model I & \multirow{3}{*}{$\begin{array}{l}\text { Model II } \\
-0.21 * * * \\
(0.07)\end{array}$} & \multirow{3}{*}{$\begin{array}{l}\text { Model III } \\
-0.23 * * * \\
(0.07)\end{array}$} & \multirow{3}{*}{$\begin{array}{l}\text { Model IV } \\
-0.20 * * * \\
(0.07)\end{array}$} \\
\hline \multirow[t]{2}{*}{ area-effect (labor market) } & & & $-0.25 * * *$ & & & \\
\hline & & & $(0.07)$ & & & \\
\hline \multirow{2}{*}{$\begin{array}{l}\text { area-effect (housing } \\
\text { market) }\end{array}$} & $-0.06 * * *$ & & & & & \\
\hline & $(0.02)$ & & & & & \\
\hline \multirow[t]{2}{*}{ Historic centre } & 0.01 & & $0.07^{* * *}$ & $0.05^{* * *}$ & $0.05^{* * *}$ & $0.03 * *$ \\
\hline & $(0.01)$ & & $(0.02)$ & $(0.01)$ & $(0.01)$ & $(0.02)$ \\
\hline \multirow[t]{2}{*}{ Share of high educated } & 0.03 & & $0.79^{* * *}$ & $0.67^{* * *}$ & $0.71^{* * *}$ & $0.51^{* * *}$ \\
\hline & $(0.05)$ & & $(0.07)$ & $(0.07)$ & $(0.07)$ & $(0.07)$ \\
\hline Ln(number of jobs within & & & $0.16^{* * *}$ & $0.15^{* * *}$ & $0.17^{* * *}$ & $0.16^{* * *}$ \\
\hline 45 minutes) & & & $(0.01)$ & $(0.01)$ & $(0.01)$ & $(0.01)$ \\
\hline \multirow{2}{*}{ Ln(population) } & $-0.01 * * *$ & & & & & \\
\hline & $(0.004)$ & & & & & \\
\hline \multirow[t]{2}{*}{ Diversity index } & 0.03 & & $-0.31 * * *$ & $1.05^{* * *}$ & $-0.38^{* *}$ & -0.09 \\
\hline & $(0.03)$ & & $(0.04)$ & $(0.32)$ & $(0.05)$ & $(0.06)$ \\
\hline \multirow[t]{2}{*}{ Quality of living index } & & & & $0.13^{* * *}$ & & $0.07^{* * *}$ \\
\hline & & & & 0.02 & & $(0.01)$ \\
\hline Interaction term & & & & $-0.21 * * *$ & & \\
\hline (quality of living $x$ & & & & $(0.06)$ & & \\
\hline \multicolumn{7}{|l|}{ diversity) } \\
\hline \multirow[t]{2}{*}{ Restaurant indicator } & & & & & $0.08^{* * *}$ & $0.10^{* * *}$ \\
\hline & & & & & $(0.02)$ & $(0.02)$ \\
\hline Time dummies & \multicolumn{2}{|l|}{ Yes } & Yes & Yes & Yes & Yes \\
\hline $\mathrm{R}^{2}$ & \multicolumn{2}{|l|}{0.33} & 0.67 & 0.70 & 0.68 & 0.71 \\
\hline No. Observations & \multicolumn{2}{|l|}{689} & 689 & 689 & 689 & 689 \\
\hline \multirow{2}{*}{\multicolumn{7}{|c|}{$\begin{array}{l}{ }^{* * *} \text { significant at } 1 \%,{ }^{* *} \text { significant at } 5 \%,{ }^{*} \text { significant at } 10 \% \text {. Heteroskedasticity-robust standard error in parentheses. } \\
\text { Source: own calculations based on CBS (GBA, SSB), NVM, ABF-Real Estate monitor. }\end{array}$}} \\
\hline & & & & & & \\
\hline \multicolumn{7}{|c|}{ Table 8 Correlation between coefficients in Table 8} \\
\hline \multirow{3}{*}{ Variables } & \multicolumn{4}{|c|}{ Variables } & & \\
\hline & Diversity index & \multirow{2}{*}{\multicolumn{2}{|c|}{$\begin{array}{l}\text { Quality of } \\
\text { living index }\end{array}$}} & \multirow{2}{*}{$\begin{array}{l}\text { Restaurant } \\
\text { indicator }\end{array}$} & & \\
\hline & & & & & & \\
\hline Diversity index & 1.000 & & & & & \\
\hline \multirow[t]{2}{*}{ Quality of living index } & -0.63 & 1.000 & & & & \\
\hline & $(0.00)$ & & & & & \\
\hline Restaurant indicator & 0.39 & -0.31 & & 000 & & \\
\hline & $(0.00)$ & $(0.00)$ & & & & \\
\hline
\end{tabular}

for the so-called 'love of variety'-effect, is an interaction term consisting of the number of restaurants per 10,000 inhabitants and the diversity of the restaurants according to [1] using the nationality of the kitchen. The restaurant indicator thus measures both the number and variety of restaurants, and can therefore be interpreted as a proxy of cosmopolitism that, as is often argued, is 
also caused by the presence of a diverse population. We measure quality of living in a municipality by using an index that brings together municipality indices on safety, population composition, residential dwelling composition, private amenities, social coherence, and the presence of natural amenities (see Annex 1 for a more detailed description). As expected, these variables are significantly correlated (see Table 8), introducing multicollinearity in our remaining estimations. Nevertheless, we think their inclusion in our model generates some valuable insights. We partly correct for the problem by including interaction terms in our model and note that the results of the remaining estimations should be interpreted with caution.

The additional estimations in Table 7 show that when we control for the quality of living index the observed negative effect of cultural diversity on the local area effect in the housing market (model I) not only disappears but even becomes significantly positive (model II). The positive and significant coefficient for the quality of living index in model II indicates that the more favourable the living conditions in a municipality are, the higher the local area effect in the housing market. Since migrants more often have relatively low incomes, they tend to live in relatively low-quality areas, as is confirmed by the negative correlation between these two variables (see Table 8). Hence, the quality of living index serves as a channel through which migrants impact the local area effect in the housing market. The overall positive effect of cultural diversity on rent residuals, which remains after indirectly controlling for the socio-economic characteristics of migrants through the quality of living index, suggests that migrant diversity leads to higher utility levels, possibly through product variety. Table 8 shows that the correlation between the diversity index and the restaurant indicator indeed is positive and significant. Model III confirms this conjecture, by showing a positive and significant impact of the variety of restaurants ('cosmopolitism') on the rent residuals. Also, from model III in Table 7 it can be seen that the omission of the quality of living index in this model makes the diversity index to become negative again.

When we include both the quality of living index and the restaurant indicator, the diversity index just becomes insignificant (model IV). This suggests that the negative effect of the relatively 
Table 9 Extended OLS regression results for equation [11]

\begin{tabular}{|c|c|c|c|c|c|c|c|}
\hline \multirow[t]{2}{*}{ Variables } & \multicolumn{7}{|c|}{ Area-year effect (housing market) } \\
\hline & Model I & Model II & Model III & Model IV & Model V & Model VI & Model VII \\
\hline area-effect & $-0.25 * * *$ & $-0.21 * * *$ & $-0.26 * * *$ & $-0.19 * * *$ & $-0.25 * * *$ & $-0.26 * * *$ & $-0.22 * * *$ \\
\hline $\begin{array}{l}\text { (labor } \\
\text { market) }\end{array}$ & $(0.07)$ & $(0.07)$ & $(0.07)$ & $(0.07)$ & $(0.07)$ & $(0.07)$ & $(0.07)$ \\
\hline Historic & $0.07 * * *$ & $0.05 * * *$ & $0.06 * * *$ & $0.04 * * *$ & $0.07 * * *$ & $0.05 * * *$ & $0.03 * *$ \\
\hline centre & $(0.02)$ & $(0.01)$ & $(0.01)$ & $(0.01)$ & $(0.01)$ & $(0.01)$ & $(0.02)$ \\
\hline Share of high & $0.79 * * *$ & $0.67 * * *$ & $0.73 * * *$ & $0.52 * * *$ & $0.81 * * *$ & $0.64 * * *$ & $0.49 * * *$ \\
\hline educated & $(0.07)$ & $(0.07)$ & $(0.07)$ & $(0.07)$ & $(0.07)$ & $(0.07)$ & $(0.07)$ \\
\hline Ln(number of & $0.16^{* * *}$ & $0.15^{* * *}$ & $0.16^{* * *}$ & $0.11 * * *$ & $0.16^{* * *}$ & $0.17 * * *$ & $0.16^{* * *}$ \\
\hline jobs within & $(0.01)$ & $(0.01)$ & $(0.01)$ & $(0.01)$ & $(0.01)$ & $(0.01)$ & $(0.01)$ \\
\hline 45 minutes) & & & & & & & \\
\hline \multirow[t]{2}{*}{ Diversity } & $-0.31 * * *$ & $1.05^{* * *}$ & $-0.15^{* *}$ & $0.16^{* *}$ & $-0.36 * * *$ & $-0.32 * * *$ & -0.08 \\
\hline & $(0.04)$ & $(0.32)$ & $(0.06)$ & $(0.07)$ & $(0.07)$ & $(0.06)$ & $(0.06)$ \\
\hline Quality of & & $0.13^{* * *}$ & & & & & $0.07 * * *$ \\
\hline living index & & $(0.02)$ & & & & & $(0.01)$ \\
\hline Interaction & & $-0.21 * * *$ & & & & & \\
\hline term $^{a}$ & & $(0.06)$ & & & & & \\
\hline \multirow[t]{2}{*}{ Safety } & & & $0.002 * * *$ & & & & \\
\hline & & & $(0.001)$ & & & & \\
\hline Interaction & & & $-0.004 * *$ & & & & \\
\hline term $^{a}$ & & & $(0.002)$ & & & & \\
\hline Population & & & & $0.01 * * *$ & & & \\
\hline composition & & & & $(0.001)$ & & & \\
\hline Interaction & & & & $-0.01 * * *$ & & & \\
\hline term $^{a}$ & & & & $(0.002)$ & & & \\
\hline Dwelling & & & & & 0.001 & & \\
\hline composition & & & & & $(0.001)$ & & \\
\hline Interaction & & & & & $-0.004^{*}$ & & \\
\hline term $^{a}$ & & & & & $(0.002)$ & & \\
\hline Restaurant & & & & & & $0.09 * * *$ & $0.10^{* * *}$ \\
\hline indiactor & & & & & & $(0.02)$ & $(0.02)$ \\
\hline Ln(foreign & & & & & & $-0.04 *$ & -0.02 \\
\hline shops) & & & & & & $(0.02)$ & $(0.02)$ \\
\hline Share of & & & & & & $0.69 * * *$ & $0.38 * *$ \\
\hline int.schools & & & & & & $(0.18)$ & $(0.18)$ \\
\hline Share of & & & & & & $-0.94 * * *$ & $-0.58 * *$ \\
\hline foreign & & & & & & $(0.27)$ & $(0.27)$ \\
\hline schools & & & & & & & \\
\hline $\begin{array}{l}\text { Time } \\
\text { dummies }\end{array}$ & Yes & Yes & Yes & Yes & Yes & Yes & Yes \\
\hline $\mathrm{R}^{2}$ & 0.67 & 0.70 & 0.68 & 0.71 & 0.67 & 0.69 & 0.72 \\
\hline No. Obs. & 689 & 689 & 689 & 689 & 689 & 689 & 689 \\
\hline
\end{tabular}

${ }^{* * *}$ significant at $1 \%,{ }^{* *}$ significant at $5 \%,{ }^{*}$ significant at $10 \%$. Heteroskedasticity-robust standard error in parentheses. Source: own calculations based on CBS (GBA, SSB), NVM, ABF-Real Estate monitor.

${ }^{a}$ The interaction term is diversity times the component of the quality of living index used in the model, i.e. in model $V$ it is the diversity index times dwelling composition. 
poor socio-economic position of migrants through the quality of living index outweighs the positive effect of the migrant-induced consumer amenities as proxied by the restaurant indicator.

In Table 9 we present the results of a further investigation into these relations, through inclusion of some of the partial indicators of the quality of living index (models III, IV, V). When including safety, the coefficient of the diversity index becomes $50 \%$ smaller, but is still significantly negative. When including the indicator for the population composition, the diversity index becomes positive and significant, again indicating that after controlling for the socio-economic position of migrants, their impact on the attractiveness of an area is positive. When including the type of dwelling composition, the diversity index becomes negative, but only the interaction term of dwelling composition and diversity is negative and significant at the $10 \%$ level. In sum, these results provide further indication of sorting of migrants into low-quality neighbourhoods. However, more research on the neighbourhood level is required to present more conclusive evidence.

We conclude our analysis by having a closer look at the interaction between the labour and housing market. As argued before, ignoring this interdependent relationship - that may manifest itself in various ways - may lead to biased estimates of the economic impact of cultural diversity in cities. Throughout the first part of this study we have considered both markets parallel. In the final part of our study we have explicitly allowed for the interaction of the two markets by controlling for local housing market effects in the identification of the determinants of the local area effects in the labor market, and vice versa. More specifically, to identify the determinants of the local area effect in the labor market, i.e. wage residuals (as in [10]), we control for the population density, and the estimated area effect in the housing market (derived from [9]). To identify the determinants of the local area effect in the housing market, i.e. rent residuals, we control for job density in the labor market, and the estimated area effect in the labor market. Table 7 shows that population density and rent residuals have a significant negative impact on wage residuals. Moreover, from Table 7 it can be seen that, conversely, the area effect from the labor market has a statistically significant negative impact on the rent residuals. Together, this suggests that the labor and housing market tend to 
convert to a spatial equilibrium in which places with lower amenities have higher wage residuals, and vice versa. Areas which are attractive as residential areas because they are high in amenities are thus not the same places that are attractive for firms to locate. Or places where firms want to locate are not the same places that are attractive for residents. An example for this found effect is the attractiveness of denser cities for residential purposes because all kinds of consumer amenities are close, but the outflow of firms to municipalities at the agglomeration boundaries because land prices are much lower and accessibility higher. In addition, Table 7 shows that density of the labor market has a positive effect on the attractiveness of an area which drives up house prices. These results are robust to different specifications as regards to various municipalities and consumer amenities, as discussed above. Again, this underlines the importance of considering both the labor and housing market simultaneously in search for the impact of cultural diversity on the economies of cities.

\section{Conclusions}

We have identified the role of foreign migrants in explaining spatial disparities in wages and housing prices across Dutch cities, using individual data about home owners in Netherlands for the period 1999-2008. Our strategy aimed to distinguish between the effects of interactions-based productivity, consumption amenities and sorting of heterogeneous home owners while controlling for interactions between the labor and housing market. First we estimated a Roback-like equilibrium model in which cultural diversity affects average wages and housing prices across cities through its localized effect on both the productivity of firms and the utility of consumers. Our results indicate that cultural diversity of the population positively impacts equilibrium wages and housing prices, particularly in the largest and most densely populated cities. Second, we took advantage of the individual dimension of our panel data to evaluate to what extent this result is influenced by spatial sorting of home owners in the labour and housing market. We did so by explaining spatial disparities in wages and housing prices from respectively observed and unobserved characteristics of individual home owners, sector and house characteristics, and a local area effect that represents the unobserved local characteristics 
of, respectively, the local labor and housing market. Our results show that in both the labor market and the housing market, the positive impact of cultural diversity on, respectively, equilibrium wages and housing prices is largely driven by sorting based on unobserved individual characteristics of home owners. After controlling for home owner heterogeneity, cultural diversity no longer impacts local labor markets and negatively impacts local housing markets. Taking into account the socioeconomic position of migrants, the latter result is likely to be driven by a negative causal effect of cultural diversity on neighborhood quality that outweighs a positive effect of increased diversity in consumption goods as measured by cultural diversity of restaurants.

Clearly, an interesting topic for future research is to further explore the issue of spatial sorting in the presence of ethnic diversity. Which individuals prefer cultural diverse areas and what are the determinants for underlying processes of sorting? Is it true that people who derive a high utility from living in a multi-cultural environment may be more tolerant and constitute the 'creative class' or higher educated people (cf. Florida 2002, Olfert and Partridge 2011)? Another interesting area for future research is to further explore the role of cultural diversity in changing the attractiveness of cities. In this study we have assessed this issue from a cross-city perspective, leaving aside the fact that individuals sort themselves across neighbourhoods within cities. Preliminary evidence for The Netherlands suggests that within cities sorting is likely to be determined by consumer amenity considerations (De Groot et al. 2010). Obviously this calls into question what the role of cultural diversity is in explaining spatial disparities in wages and housing prices across different neighborhoods within the same city, and to what extent the observed patterns are driven by migrant-induced consumption amenities.

\section{References}

Alesina, A. and E. La Ferrara (2005). Ethnic Diversity and Economic Performance, Journal of Economic Literature, vol. 43, pp. 762-800.

Bajari, P. and M.E. Kahn (2005). Estimating Housing Demand with an Application to Explaining Racial Segregation in Cities, Journal of Business \& Economic Statistics, vol.23, no.1, pp. 20-33. 
Bajari, P. and M.E. Kahn (2008). Estimating Hedonic Models of Consumer Demand with an Application to Urban Sprawl, in: Baranzini, A., J. Ramirez, C. Schaerer and P. Thalmann (eds.) (2008). Hedonic Methods in Housing Markets: Pricing Environmental Amenities and Segregation, Springer, New York.

Baltagi, B.H. (1996). Econometric Analysis of Panel Data, Wily, Chichester.

Baranzini, A., J. Ramirez, C. Schaerer and P. Thalmann (eds.) (2008). Hedonic Methods in Housing Markets: Pricing Environmental Amenities and Segregation. Springer, New York.

Bartel, A.P.(1989). Where do the New U.S. Immigrants Live? Journal of Labor Economics, vol.7, no.4, pp.371-391.

Bellini, E., G.I.P. Ottaviano, D. Pinelli and G. Prarolo (2008). Cultural Diversity and Economic Performance: Evidence from European Regions, HWWI Research Paper 3-14.

Benabou, R. (1993). Workings of a City: Location, Education, and Production, The Quarterly Journal of Economics, vol. 108, no.3, pp.619-652.

Borjas, G.J. (1987). Self-Selection and the Earnings of Immigrants, The American Economic Review, vol. 77, no.4, pp.531-553.

Borjas, G.J. (1994). The Economics of Immigration, Journal of Economic Literature, vol. 32, pp.16671717.

Borjas, G.J. (1995). Ethnicity, Neighbohoods, and Human-Capital Externalities, The American Economic Review, vol. 85, no. 3, pp. 365-390.

Borjas, G.J. (2001). Does Immigration Grease the Wheels of the Labor Market? Brookings Papers on Economic Activity, vol. 1, pp.69-133.

Borjas , G.J. (2003). The Labor Demand Curve is Downward Sloping: Reexamining the Impact of Immigration on the Labor Market, The Quarterly Journal of Economics, vol. 118, no.4, pp. 13351374.

Beugelsdijk,S. and R. Maseland (2010). Culture in Economics, Cambridge University Press.

Card, D. (1990). The Impact of the Mariel Boatlift on the Miami Labor Market, Industrial and Labor Relations Review, no. 43, 245-257.

Card, D. (2001). Immigrant Inflows, Native Outflows, and the Local Market Impacts of Higher Immigration, Journal of Labor Economics, vol. 19, no. 1, pp.22-64.

Card, D. and J. Niardo (2000). Do Immigrant Inflows lead to Native Outflows? The American Economic Review, vol.90, no.2, pp.360-367.

Chiswick, B.R. (1999). Are Immigrants Favorable Self-Selected? The American Economic Review, vol. 89, no. 2, pp. 181-185.

Combes, P., G. Duranton and L. Gobillon (2008). Spatial Wage Disparities: Sorting Matters!, Journal of Urban Economics, no. 63, pp. 723-742.

Cutler, D.M., E.L. Glaeser and J.L Vigor (1999). The Rise and Decline of the American Ghetto. Journal of Political Economy, vol.107, no. 3, pp.455-506.

De Groot, H, G. Marlet, C. Teulings and W. Vermeulen (2010). Stad en Land, Centraal Planbureau.

Duranton, G. and D. Puga (2001). Nursery Cities: Urban Diversity, Process Innovation, and the Life Cycle of Products, The American Economic Review, vol. 91, no. 5, pp. 1454-1477.

Florida, R. (2002). The Rise of the Creative Class: and How it's Transforming Work, Leisure, Community and Everyday Life, New York, Basic.

Glaeser, E.L., J. Kolko and A. Saiz (2001). Consumer City, Journal of Economic Geography, vol. 1, pp. 27-50.

Hoehn, J.P., M.C. Berger and G.C. Blomquist (1987). A Hedonic Model of Interregional Wages, Rents, and Amenity Values, Journal of Regional Science, vol.27, no.4, pp.605-620. 
Jacobs, J. (1969). The Economy of Cities, Vintage Books, New York.

Lazear, E. (1999). Globalization and the Market for team-mates, Economic Journal, vol. 109, no. 454, pp. 15-40.

Marlet, G. (2009). De Aantrekkelijke Stad, VOC Uitgevers, Nijmegen.

Olde Kalter, M., H van der Loop and L. Harms (2010). Verklaring Mobiliteit en Bereikbaarheid 19852008, Kennisinstituut voor Mobiliteitsbeleid.

Olfert, M.R. and M. Partridge (2011). Creating the Cultural Community: Ethnic Diversity vs. Agglomeration, Spatial Economic Analysis Special Issue: Interregional Migration, vol. 6, no.1, pp. 25-56.

Ottaviano, G.I.P. and G. Peri (2005). Cities and Cultures, Journal of Urban Economics, vol. 58, pp. 304337.

Ottaviano, G.I.P. and G. Peri (2006). The Economic Value of Cultural Diversity: Evidence from U.S. Cities, Journal of Economic Geography, vol.6, pp. 9-44.

Quigley, J.M. (1998). Urban Diversity and Economic Growth, The Journal of Economic Perspectives, vol. 12 , no. 2 , pp. 127-138.

Roback, J. (1982). Wages, Rents, and the Quality of Life, The Journal of Political Economy, vol. 90, no, 6, pp. 1257-1278.

Rosen, S. (1974). Hedonic Prices and Implicit Markets: Product Differentiation in Pure Competition, The Journal of Political Economy, vol. 82, no. 1, pp. 34-55.

Saiz, A. (2003). Room in the Kitchen for the Melting Pot: Immigration and Rental Prices, The Review of Economics and Statistics, vol. 85, no. 3, pp. 502-521.

Saiz, A. (2007). Immigration and Housing Rents in American Cities, Journal of Urban Economics, vol.61, no.2, pp.345-371.

Saiz, A. and S. Wachter (2006). Immigration and the Neighborhood, FED Philadelphia working paper no. 06-22.

Scott, A.J. (2010). Jobs or Amenities? Destination Choices of Migrant Engineers in the U.S.A., Papers in Regional Science, vol.89, no.1, pp.43-64. 


\section{Annex 1 - Data description}

\begin{tabular}{|c|c|c|c|}
\hline Variable & Description & $\begin{array}{l}\text { Period/ } \\
\text { source }\end{array}$ & Remarks \\
\hline $\begin{array}{l}\text { Municipality } \\
\text { of residence }\end{array}$ & $\begin{array}{l}\text { Municipality where } \\
\text { home owner has bought } \\
\text { a house (housing market } \\
\text { area) }\end{array}$ & $\begin{array}{l}\text { 1999-2008 } \\
\text { CBS- GBA }\end{array}$ & $\begin{array}{l}\text { House buyers are identified by selecting the individuals registered at the address of a sold house within approximately } 9 \text { months } \\
\text { ( } 275 \text { days) and at least staying there } 90 \text { days. Households with } 1 \text { or } 2 \text { adults are selected. If we have a household with } 2 \text { adults, } \\
\text { who both have an income from (self)-employed work, we assume both wages are used for financing the house. This is a very } \\
\text { realistic assumption in the Netherlands. It is thus possible that one transaction in the dataset has two home owners. We consider } \\
\text { both owners individuals who bought a house and estimate the rent and wage equation for both owners individually. }\end{array}$ \\
\hline $\begin{array}{l}\text { Municipality } \\
\text { of work }\end{array}$ & $\begin{array}{l}\text { Municipality where } \\
\text { home owner works in } \\
\text { the year of purchasing } \\
\text { the house (labour } \\
\text { market area) }\end{array}$ & $\begin{array}{l}1999-2008 \\
\text { CBS- SSB-Banen, } \\
\text { SSB-zelfst, ABR }\end{array}$ & $\begin{array}{l}\text { For each home owner the municipality of work is determined either by survey data, or by looking at the location of a firm and the } \\
\text { location of the subsidiaries of the firm. If the firm has no subsidiaries, the location of the head quarters (HQ) of the firm is the } \\
\text { municipality of work. If the firm has multiple subsidiaries, the worker is assigned to the subsidiary that is closest to the residential } \\
\text { municipality of the worker based on Euclidean distance. We construct travel time costs for workers that commute between } \\
\text { municipalities. According to research on Dutch mobility (Olde Kalter et al. 2010) the average travel speed for commuting is } 45 \\
\mathrm{~km} / \mathrm{h} \text { (or } 0.75 \mathrm{~km} / \text { minute) (by car) and the average value of time is } € 8 \text { per hour (or } € 0.133 / \text { minute). Since we have only Euclidean } \\
\text { distance, we multiply the distance by } 1.3 \text { to approach real distances. Considering } 261 \text { days of work per year and commuting to and } \\
\text { from work, we construct the yearly travel time costs. }\end{array}$ \\
\hline Wage & $\begin{array}{l}\text { Yearly wage of the home } \\
\text { owner }\end{array}$ & $\begin{array}{l}1999-2008 \\
\text { CBS- SSB-Banen, } \\
\text { SSB-zelfst }\end{array}$ & $\begin{array}{l}\text { Prices are constant } 2008 \text { prices. For employed individuals, the fiscal wage is taken, divided by the number of days worked, times } \\
261 . \text { If individuals have had multiple jobs in } 1 \text { year, the arithmetic mean is taken. Wages from jobs held less than } 30 \text { days are } \\
\text { removed from the dataset. Individuals with a yearly wage of between } € 16,500 \text { (the minimum wage) and } € 15,000,000 \text { are used in } \\
\text { the analysis. For self-employed, the gross profit is taken from the tax income statements. Only individuals that were self-employed } \\
\text { throughout our sample period ( } 1999 \text { to } 2008 \text { ) and that earned a stable profit are selected. Self-employed with a profit less than } \\
€ 16,500 \text { are removed from the dataset. The profit is cut off at } € 10,000,000 \text {. The wage is corrected for yearly commuting-time } \\
\text { costs. }\end{array}$ \\
\hline Age & Age of the home owner & $\begin{array}{l}1999-2008 \\
\text { CBS- GBA }\end{array}$ & Of the owners, $54 \%$ is male and $46 \%$ is female. The average age is 35 years. \\
\hline Sector & $\begin{array}{l}\text { Industry of employment } \\
\text { of the home owner }\end{array}$ & $\begin{array}{l}\text { 1999-2008 } \\
\text { CBS-SSB-Banen, } \\
\text { SSB-zelfst }\end{array}$ & $\begin{array}{l}\text { According to SBI-coding of } 15 \text { sectors. If a home owner has multiple jobs in different sectors, the sector from which the most wage } \\
\text { is generated is taken. }\end{array}$ \\
\hline Housing price & $\begin{array}{l}\text { Housing price per square } \\
\text { meter }\end{array}$ & $\begin{array}{l}\text { 1999-2008 } \\
\text { NVM }\end{array}$ & $\begin{array}{l}\text { Prices are constant } 2008 \text { prices. Transactions are selected between } € 30,000 \text { and } € 15,000,000 \text { and with a minimum floor area of } 30 \\
\mathrm{~m}^{2} \text {. All houses sold for more than twice or less than one third of the initial offer price are excluded. }\end{array}$ \\
\hline $\begin{array}{l}\text { Maintenance } \\
\text { outside }\end{array}$ & $\begin{array}{l}\text { State of outside } \\
\text { maintenance }\end{array}$ & $\begin{array}{l}\text { 1999-2008 } \\
\text { NVM }\end{array}$ & Dummy variable equals 1 if state of maintenance is good \\
\hline $\begin{array}{l}\text { Maintenance } \\
\text { inside } \\
\end{array}$ & $\begin{array}{l}\text { State of inside } \\
\text { maintenance }\end{array}$ & & \\
\hline $\begin{array}{l}\text { Pre-1930 } \\
\text { construction }\end{array}$ & $\begin{array}{l}\text { House constructed } \\
\text { before } 1930\end{array}$ & $\begin{array}{l}\text { 1999-2008 } \\
\text { NVM }\end{array}$ & Dummy variable equals 1 if house is constructed before 1930 \\
\hline House type & Type of dwelling & 1999-2008 & Houses are categorised according to 21 house and apartment types \\
\hline
\end{tabular}




\begin{tabular}{|c|c|c|c|}
\hline & & NVM & \\
\hline $\begin{array}{l}\text { Diversity } \\
\text { index }\end{array}$ & $\begin{array}{l}\text { Cultural diversity index } \\
\text { per municipality }\end{array}$ & $\begin{array}{l}\text { 1999-2008 } \\
\text { CBS- GBA }\end{array}$ & According to [1]. Based on the country of birth of the parents. \\
\hline $\begin{array}{l}\text { Diversity } \\
\text { index among } \\
\text { migrants }\end{array}$ & $\begin{array}{l}\text { Cultural diversity index } \\
\text { per municipality } \\
\text { excluding the natives as } \\
\text { a cultural group }\end{array}$ & $\begin{array}{l}\text { 1999-2008 } \\
\text { CBS- GBA }\end{array}$ & According to [1]. Based on the country of birth of the parents. \\
\hline $\begin{array}{l}\text { Share of } \\
\text { foreigners }\end{array}$ & $\begin{array}{l}\text { Share of immigrants in a } \\
\text { municipality }\end{array}$ & $\begin{array}{l}\text { 1999-2008 } \\
\text { CBS- GBA }\end{array}$ & Based on the country of birth of the parents. \\
\hline $\begin{array}{l}\text { Share of } \\
\text { foreigners- } \\
\text { Instrumental } \\
\text { Variable (IV) } \\
\end{array}$ & $\begin{array}{l}\text { Instrumented share of } \\
\text { immigrants in a } \\
\text { municipality }\end{array}$ & $\begin{array}{l}\text { 1995-2008 } \\
\text { CBS- GBA }\end{array}$ & According to [6]. Based on the country of birth of the parents. \\
\hline $\begin{array}{l}\text { Diversity } \\
\text { index-IV }\end{array}$ & $\begin{array}{l}\text { Instrumented cultural } \\
\text { diversity index per } \\
\text { municipality } \\
\end{array}$ & $\begin{array}{l}\text { 1995-2008 } \\
\text { CBS- GBA }\end{array}$ & According to [1] and [6]. Based on the country of birth of the parents. \\
\hline $\begin{array}{l}\text { Number of } \\
\text { jobs } \\
\text { reachable in } \\
45 \text { minutes } \\
\end{array}$ & $\begin{array}{l}\text { The number of jobs } \\
\text { reachable within } 45 \\
\text { minutes of commuting } \\
\text { time from a municipality }\end{array}$ & $\begin{array}{l}\text { 1996-2006 } \\
\text { ABF real estate } \\
\text { monitor }\end{array}$ & $\begin{array}{l}\text { The number of jobs in a municipality plus the number of jobs in each municipality that is within } 45 \text { minutes of travel time. The } \\
\text { average travel speed for commuting is } 45 \mathrm{~km} / \mathrm{h} \text { (or } 0.75 \mathrm{~km} / \text { minute) (by car). As we have only Euclidean distance from } \\
\text { municipality centre to municipality centre, we multiply the distance by } 1.3 \text { to approach real distances. Number of jobs in } 2007 \text { and } \\
2008 \text { are induced based on average growth rates of jobs between 1996-2006 }\end{array}$ \\
\hline Population-IV & $\begin{array}{l}\text { Number of inhabitants of } \\
\text { a municipality }\end{array}$ & $\begin{array}{l}1972-2007 \\
A B F\end{array}$ & According to $[6]$. \\
\hline $\begin{array}{l}\text { Share of high } \\
\text { educated }\end{array}$ & $\begin{array}{l}\text { The share of high } \\
\text { educated in the } \\
\text { municipality }\end{array}$ & $\begin{array}{l}\text { 1999-2008 } \\
\text { CBS- OPLNIV }\end{array}$ & People holding at least a bachelor degree are highly educated. \\
\hline $\begin{array}{l}\text { Income per } \\
\text { capita }\end{array}$ & $\begin{array}{l}\text { Income per capita in a } \\
\text { municipality }\end{array}$ & $\begin{array}{l}\text { 1999-2008 } \\
\text { CBS- SSB-Banen, } \\
\text { SSB-zelfst }\end{array}$ & \\
\hline Population & $\begin{array}{l}\text { Number of inhabitants of } \\
\text { a municipality }\end{array}$ & $\begin{array}{l}1972-2007 \\
\text { ABF }\end{array}$ & Population in 2008 is induced using average growth rates of population between 1999-2006 \\
\hline $\begin{array}{l}\text { Location } \\
\text { quotient }\end{array}$ & Location quotient & $\begin{array}{l}\text { 1996-2007 } \\
\text { ABF }\end{array}$ & $\begin{array}{l}\text { The LQ for area } a \text { in country } n \text { with } k \text { sectors is: } \frac{E_{k a}}{E_{a}} / \frac{E_{k n}}{E_{n}} \text {. Employment in each sector for } 2008 \text { is induced based on average growth } \\
\text { rates of employment in each sector between } 1996-2007\end{array}$ \\
\hline RDI & Relative diversity index & $\begin{array}{l}\text { 1996-2007 } \\
\text { ABF }\end{array}$ & $\begin{array}{l}\text { The RDI for area } a \text { in country } n \text { with } k \text { sectors is: } R D I_{a}=1 / \sum_{k=1}^{K}\left|\frac{E_{k a}}{E_{a}}-\frac{E_{k n}}{E_{n}}\right| . \text { Employment in each sector for } 2008 \text { is induced } \\
\text { based on average growth rates of employment in each sector between 1996-2007 }\end{array}$ \\
\hline $\begin{array}{l}\text { Historic } \\
\text { centre }\end{array}$ & Historic centre & NVM & $\begin{array}{l}\text { Dummy variable is } 1 \text { if, between } 1995 \text { and 2009, more than } 15 \% \text { of the houses sold in a municipality were built between } 1500 \text { and } \\
1905 \text { or more than } 23 \% \text { of the houses sold in a municipality were built between } 1905 \text { and } 1930 .\end{array}$ \\
\hline $\begin{array}{l}\text { Quality of } \\
\text { living index }\end{array}$ & $\begin{array}{l}\text { Municipality index for } \\
\text { quality of living }\end{array}$ & $\begin{array}{l}1998,2002, \\
2006,2008,\end{array}$ & $\begin{array}{l}\text { All values are deviations from National averages. As the index is available for } 5 \text { year and we have averaged the dataset to } 5 \text { 2-year } \\
\text { time intervals, } 1998 \text { is linked to } 1999-2000,2002 \text { is linked to 2001-2002, } 2006 \text { is linked to 2005-2006, and } 2008 \text { is linked to 2007- }\end{array}$ \\
\hline
\end{tabular}




\begin{tabular}{|c|c|c|c|}
\hline Safety & Safety in a municipality & \multirow{3}{*}{$\begin{array}{l}2010 \\
\text { Ministry of } \\
\text { Internal Affairs- } \\
\text { Leefbaarometer }\end{array}$} & \multirow{3}{*}{$\begin{array}{l}\text { 2008. The overall index is constructed out of: safety, population composition, residential dwelling composition, private amenities, } \\
\text { social coherence, and presence of natural amenities (sea, forest or nature reserve). Safety consists of: vandalism, disturbance of } \\
\text { public order, violent crimes, car theft, discomfort. Population composition consists of: share of unemployed, dominance of less } \\
\text { than } 2 \text { times standard income, dominance minimum income, dominance of more than } 2 \text { times standard income, share of non- } \\
\text { Western migrants, share of high educated. Dwelling composition consists of: dominance of detached houses, duplex, apartment } \\
\text { buildings over } 4 \text { floors, apartments, farm houses, urban prestigious houses, suburban prestigious houses, age of construction, } \\
\text { density, share of social housing. }\end{array}$} \\
\hline $\begin{array}{l}\text { Population } \\
\text { composition }\end{array}$ & $\begin{array}{l}\text { Population composition } \\
\text { in a municipality }\end{array}$ & & \\
\hline $\begin{array}{l}\text { Dwelling } \\
\text { composition }\end{array}$ & $\begin{array}{l}\text { Composition of housing } \\
\text { stock in a municipality }\end{array}$ & & \\
\hline $\begin{array}{l}\text { Restaurant } \\
\text { indicator }\end{array}$ & $\begin{array}{l}\text { Number of restaurants } \\
\text { per } 10,000 \text { inhabitants } \\
\text { times restaurant } \\
\text { diversity }\end{array}$ & $\begin{array}{l}\text { 1996-2007 } \\
\text { ABF real estate } \\
\text { monitor }\end{array}$ & $\begin{array}{l}\text { Variable contains the number of restaurants per 10,000 inhabitants per municipality, and a diversity index according to [1] based } \\
\text { on the nationality of the kitchen. In total, } 20 \text { categories of kitchen nationality are distinguished of which one is considered } \\
\text { "Dutch". Number of restaurants in } 2008 \text { is induced based on the average growth rate of restaurants between 1996-2007 }\end{array}$ \\
\hline Foreign shops & $\begin{array}{l}\text { Number of foreign shops } \\
\text { per } 10,000 \text { inhabitants }\end{array}$ & $\begin{array}{l}\text { 1999-2008 } \\
\text { CBS-ABR }\end{array}$ & $\begin{array}{l}\text { The number of firms in the Netherlands that are classified as supermarkets selling foreign products according to the SBI- } \\
\text { classification of firms (standard firm classification). Per 10,000 inhabitants per municipality }\end{array}$ \\
\hline $\begin{array}{l}\text { Share of } \\
\text { international } \\
\text { schools }\end{array}$ & $\begin{array}{l}\text { Share of international } \\
\text { schools in the } \\
\text { municipality }\end{array}$ & \multirow[t]{2}{*}{$\begin{array}{l}2009 \\
\text { Ministry of } \\
\text { education }\end{array}$} & \multirow{2}{*}{$\begin{array}{l}\text { Because of historical reasons, the Dutch schooling system is build upon religion (Catholic or Protestant), or life principles (like } \\
\text { Montessori education). The curriculum of each elementary school is fixed, but outside the curriculum, schools can choose to } \\
\text { educate in, for example, bible lessons, celebrate Christmas etc. Public (in the sense of no religious beliefs) schools are the majority } \\
\text { in most municipalities, followed by either Catholic or Protestant schools. The Netherlands has a few international (private) } \\
\text { schools. We consider Islamic, Jewish, and Hindustani schools to be "foreign", or migrant induced. We have calculated the share of } \\
\text { international, foreign and natives schools in our sample. }\end{array}$} \\
\hline $\begin{array}{l}\text { Share of } \\
\text { foreign } \\
\text { schools }\end{array}$ & $\begin{array}{l}\text { Share of foreign schools } \\
\text { in the municipality }\end{array}$ & & \\
\hline
\end{tabular}




\section{Annex 2- Additional Tables and Figures}

Table $2 a$ Selection of municipalities in the analysis by population size

\begin{tabular}{ccc}
\hline Population size & Number of municipalities & $\begin{array}{c}\text { Number of municipalities in } \\
\text { the sample }\end{array}$ \\
\hline$>250,000$ & 4 & 4 \\
$150,000-250,000$ & 8 & 8 \\
$100,000-150,000$ & 14 & 13 \\
$50,000-100,000$ & 43 & 38 \\
$20,000-50,000$ & 191 & 101 \\
$10,000-20,000$ & 126 & 12 \\
$5,000-10,000$ & 39 & 0 \\
$<5,000$ & 6 & 0 \\
\hline
\end{tabular}

Throughout the analysis, the municipality categorization of 2008 is used

The 25 largest municipalities in the analysis are:

Groningen, Almere, Emmen, Enschede, Zwolle, Apeldoorn, Arnhem, Den Bosch, Amsterdam,

Utrecht, Ede, Nijmegen, Amersfoort, Haarlem, Haarlemmermeer, Zaanstad, Dordrecht, Den Haag,

Leiden, Rotterdam, Zoetermeer, Breda, Eindhoven, Tilburg, Maastricht.

Table $2 b$ Average area-year fixed effects

\begin{tabular}{lrrrr}
\hline Effect & \multicolumn{2}{c}{ Area-year effect labor market } & Area-year effect housing market \\
(indexed) & 100 & Amsterdam & (indexed) \\
\hline Highest & Noordwijkerhout & 68 & Nunspeet & 100 \\
& Aa \& Hunze & 35 & Noordwijk & 92 \\
& Ouder-Amstel & 30 & Eloemendaal & 89 \\
& Nieuwerkerk a/d ljssel & 6 & & 84 \\
& Winschoten & & Hoogezand-Sappemeer & 5 \\
Lowest & Steenwijkerland & -91 & Delfzijl & 5 \\
& Zeewolde & -110 & Terneuzen & 4 \\
& Laren & -118 & Veendam & 2 \\
& Raalte & -121 & Winschoten & -13 \\
\hline
\end{tabular}

Source: own calculations based on CBS (GBA, SSB), NVM 